\title{
Macroprudential Policy, Countercyclical Bank Capital Buffers, and Credit Supply: Evidence from the Spanish Dynamic Provisioning Experiments
}

\section{Gabriel Jiménez}

Banco de España

\section{Steven Ongena}

University of Zurich, Swiss Finance Institute, and Centre for Economic Policy Research

\author{
José-Luis Peydró \\ ICREA-Universitat Pompeu Fabra, Barcelona Graduate School of Economics, Centre de Recerca \\ en Economia Internacional, Imperial College London, and Centre for Economic Policy Research
}

\section{Jesús Saurina}

Banco de España

\begin{abstract}
To study the impact of macroprudential policy on credit supply cycles and real effects, we analyze dynamic provisioning. Introduced in Spain in 2000, revised four times, and tested in its countercyclicality during the crisis, it affected banks differentially. We find that dynamic provisioning smooths credit supply cycles and, in bad times, supports firm performance. A 1 percentage point increase in capital buffers extends credit to firms by 9 percentage points, increasing firm employment ( 6 percentage points) and survival (1 percentage point). Moreover, there are important compositional effects in credit supply related to risk and regulatory arbitrage by nonregulated and regulated but less affected banks.
\end{abstract}

We thank four anonymous referees, Tobias Adrian, Ugo Albertazzi, Franklin Allen, Laurent Bach, Olivier Blanchard, Bruce Blonigen, Patrick Bolton, Markus Brunnermeier, Elena

Electronically published November 6, 2017

[ Journal of Political Economy, 2017, vol. 125, no. 6]

(C) 2017 by The University of Chicago. All rights reserved. $0022-3808 / 2017 / 12506-0003 \$ 10.00$ 


\section{Introduction}

Banking crises are recurrent phenomena that generally come after periods of strong credit growth (Kindleberger 1978; Gourinchas and Obstfeld 2012; Schularick and Taylor 2012). Their damaging real effects (Reinhart and Rogoff 2009) have generated a broad agreement among academics and policy makers that financial regulation needs to get a macroprudential dimension that aims to lessen the negative externalities from the financial to the macro real sector, as in a credit crunch caused by the weakening in banks' balance sheets (Bernanke 1983).

Time-varying macroprudential policy tools can be used to address these cyclical vulnerabilities in systemic risk (Yellen 2011). Under the new international regulatory framework for banks-Basel III-regulators agreed to vary minimum capital requirements over the cycle by instituting coun-

Carletti, Gabriel Chodorow-Reich, Hans Dewachter, Mathias Dewatripont, Jordi Gali, Leonardo Gambacorta, John Geanakoplos, Refet Gürkaynak, Michel Habib, Lars Peter Hansen, Philipp Hartmann, Thorsten Hens, Anil Kashyap, Roni Kisin, Nobuhiro Kiyotaki, Luc Laeven, Nellie Liang, Atif Mian, Frederic Mishkin, Paolo Emilio Mistrulli, Janet Mitchell, Antonio Moreno, Daniel Paravisini, Manju Puri, Adriano Rampini, Jean-Charles Rochet, Kasper Roszbach, Julio Rotemberg, Ariel Rubinstein, Lambra Saínz Vidal, Tano Santos, Amit Seru, Chris Sims, Harald Uhlig (editor), Raf Wouters, the seminar participants at the Banco de España, Banco de Portugal, Bank of Finland, Cass Business School, CEMLAAssociation of Central Banks in Latin America and the Caribbean, Central Banks of Ireland and Hungary, Deutsche Bundesbank, European Central Bank, European University Institute (Florence), Federal Reserve Board, Swiss Financial Market Supervisory Authority (Bern), International Monetary Fund, London School of Economics, National Bank of Belgium, Columbia, Duke, Princeton, University of North Carolina (Chapel Hill), Oregon, Oxford, and Zurich, and participants at the ACPR-Banque de France Conference on Risk Taking in Financial Institutions, Regulation and the Real Economy (Paris), American Finance Association meetings (San Diego), Banca d'Italia-Centre for Economic Policy Research Conference on Macroprudential Policies, Regulatory Reform and Macroeconomic Modeling (Rome), Banque de France Conference on Firms' Financing and Default Risk During and After the Crisis (Paris), Becker-Friedman Institute for Research in Economics at the University of Chicago Conference on Macroeconomic Fragility, CAREFIN-Intesa SanPaolo-James Franck Institute Conference on Bank Competitiveness in the Post-Crisis World (Milano), Centre for Economic Policy Research-Centre de Recerca en Economia Internacional Conference on Asset Prices and the Business Cycle (Barcelona), Centre for Economic Policy Research-European Summer Symposium in Economic Theory (Gerzensee), European Economic Association Invited Session on New Approaches to Financial Regulation (Malaga), Fordham-Rensselaer Polytechnic Institute-New York University 2012 Rising Stars Conference (New York), Madrid Finance Workshop on Banking and Real Estate, National Bank of Belgium Conference on Endogenous Financial Risk (Brussels), National Bureau of Economic Research Summer Institute 2012 Meeting on Finance and Macro (Cambridge), and the University of Vienna-Oesterreichische NationalbankCentre for Economic Policy Research Conference on Bank Supervision and Resolution (Vienna) for helpful comments. Peydró acknowledges financial support from both the Spanish Ministry of Economics and Competitiveness (project ECO2012-32434) and the European Research Council Grant (project 648398). The National Bank of Belgium and its staff generously supported the writing of this paper in the framework of its October 2012 Colloquium Endogenous Financial Risk. These are our views and do not necessarily reflect those of the Banco de España, the Eurosystem, and/or the National Bank of Belgium. Data are provided as supplementary material online 
tercyclical bank capital buffers (i.e., procyclical capital requirements), which aim to achieve two macroprudential objectives at once. ${ }^{1}$ First, boosting equity or provisioning requirements in booms provides additional (countercyclical) buffers in downturns that can help mitigate credit crunches. Second, higher requirements on banks' own funds can cool credit-led booms, either because of the higher cost of bank capital or because banks internalize more of the potential social costs of credit defaults (via lower moral hazard by having more "skin in the game"). ${ }^{2}$ Countercyclical buffers could hence lessen the excessive procyclicality of credit, that is, those credit cycles that find their root causes in banks' agency frictions. ${ }^{3}$ Smoothing credit supply cycles will cause positive firm-level real effects if bank-firm relationships are valuable and credit substitution for firms is difficult in bad times.

Despite the attention now given by academics and policy makers alike to the global development of macroprudential policies, no empirical study so far has estimated the impact of a time-varying macroprudential policy tool on the supply of credit and the associated spillovers on real activity in both good and bad times. This paper aims to fill this void by analyzing a series of pioneering policy experiments with dynamic provisioning in Spain:" from its introduction in 2000:Q3, and change in 2005:Q1 during good times, to its later performance when a severe (mostly unforeseen) crisis shock struck, thus allowing one to test the countercyclical nature of the policy, and also the changes in bad times (two reductions in 2008:Q4 and in 2009:Q4 and an ad hoc increase in provisions in 2012:Q1 and Q2).

\footnotetext{
1 The common terminology we follow is that procyclical capital requirements generate countercyclical capital buffers that deal with the procyclicality of credit by the banking system. See Borio (2003), Hanson, Kashyap, and Stein (2011), Kashyap, Berner, and Goodhart (2011), and Dewatripont and Tirole (2012).

${ }^{2}$ See Diamond and Rajan (2001), Morrison and White (2005), Shleifer and Vishny (2010), Tirole (2011), and Malherbe (2015). Tax benefits of debt finance, public guarantees, and asymmetric information about banks' conditions imply that equity finance may be more costly for banks than debt finance (Freixas and Rochet 2008; Aiyar, Calomiris, and Wieladek 2014). Admati and Hellwig (2013) question whether capital costs for banks are high.

${ }^{3}$ As in Guttentag and Herring (1984), Rajan (1994), Holmstrom and Tirole (1997), Berger and Udell (2004), Ruckes (2004), Dell'Ariccia and Marquez (2006), Diamond and Rajan (2006), Allen and Gale (2007), Adrian and Shin (2011), Gersbach and Rochet (2012), and Harris, Opp, and Opp (2015). Credit cycles also stem from firms' agency frictions as in Bernanke and Gertler (1989), Kiyotaki and Moore (1997), Lorenzoni (2008), Jeanne and Korinek (2012), Farhi and Werning (2014), and Korinek and Simsek (2016), though these models can also be interpreted as dealing with banks with agency problems in their borrowing from final investors. Hence, macroprudential policy limits exposures of both lenders and borrowers (see also Freixas, Laeven, and Peydró 2015).

${ }^{4}$ There is almost no real experience on how such policies work along a credit cycle. Most of the discussions are theoretical, simulations (Repullo, Saurina, and Trucharte 2010), or policy papers (see, e.g., the International Monetary Fund paper by Lim et al. [2011]). Also, new policies like stress tests cannot be analyzed yet over a full cycle. Moreover, we designate the policy changes as "experiments," though macro policy shocks to the banking sector are never (intentionally) randomized. Therefore, both shocks and comprehensive data are necessary for identification.
} 
These shocks coupled with unique bank-, firm-, and loan-level (including loan application) data allow for identification.

Dynamic provisions - called "dynamic" as they vary over the cycle and "statistical" or "generic" as a formula is mandating their calculation-are forward-looking: Before any credit loss is recognized on an individual loan, a buffer (i.e., the dynamic provision fund) is built up from retained profits in good times to cover the realized losses in bad times (i.e., when specific provisions surpass its formula-based average over a credit cycle). The dynamic provision fund has a regulatory ceiling and floor. The required provisioning in good times is over and above the specific loan loss provisions, and there is a regulatory reduction of this provisioning in bad times, when bank profits are low and new shareholders' funds are costly to obtain. Dynamic provision funds are now tier 2 regulatory capital. Hence, dynamic provisions are procyclical, thus constituting countercyclical capital buffers that can be used in crisis times. ${ }^{5}$

The policy experiment in good times we focus on is the introduction of dynamic provisioning in 2000:Q3, which by construction entailed an additional nonzero provision requirement for most banks, but - and this is crucial for our estimation purposes - with a widely different formulabased provision requirement across banks. Next, we analyze the countercyclical workings of the dynamic provision funds built up by the banks as of 2007:Q4 following the crisis shock in 2008:Q3, and we also follow a series of policy experiments in bad times, that is, the sudden lowering of the floor of the dynamic provision funds from 33 percent to 10 percent in 2008:Q4 and to 0 percent in 2009:Q4 (that allowed for a greater release of buffers for many banks) and, given that the overall precrisis level of provisions was relatively low (1.25 percent of total credit) and basically depleted in 2011, the 2012 increase in provisioning that banks needed to make on the basis of their exposure to construction and real estate firms to clean up their balance sheets.

To identify the availability of credit and the associated real effects, we employ a comprehensive credit register that comprises bank-firm-level data on all outstanding business loan contracts and balance sheets of all banks collected by the supervisor, in conjunction with firm-level data from the Spanish Mercantile Register. We calculate the total credit exposures by each bank to each firm in each quarter, from 1999:Q1 to 2013:Q3, a time period that allows us to study the impact of dynamic provisions along a full cycle, with an unexpected crisis in the middle. ${ }^{6}$ We analyze

\footnotetext{
${ }^{5}$ See Saurina (2009b) for a detailed explanation of dynamic provisions' rationale and workings.

${ }^{6}$ From 1999 to 2008 Spain went through a strong credit expansion and from 2008 onward suffered a severe recession. In 2007, all major central banks, international organizations, and private forecasters forecasted strong economic growth in 2008. The GDP in Spain grew by 3.6 percent in 2007 , but by 0.9 percent in 2008, and after 2008, GDP con-
} 
changes in committed credit volume, on both the intensive and extensive margins, and also credit drawn, maturity, collateral, and cost. We also use loan applications made by firms to new banks to analyze substitution effects. Depending on their credit portfolio, banks were differentially affected by the various policy experiments. Therefore, we perform a difference-indifference analysis in which we compare before and after each shock differently affected banks' lending at the same time to the same firm (Khwaja and Mian 2008; Jiménez et al. 2012). Though we analyze the same bank (firm) before and after the shock, in robustness we further control for up to 32 bank variables and key bank-firm and loan characteristics. We also exploit differences across various subsamples, components of the risk formula, and regulation (i.e., foreign branches in Spain were not regulated with respect to dynamic provisioning). Finally, by matching credit with firm balance sheets and the register on firm deaths, we also assess the effects on firm-level total assets, employment, and survival.

In good times we find that banks that have to provision more cut committed credit more to the same firm after the shock-and not beforethan other banks. These findings also hold for the extensive margin of credit and for credit drawn, maturity, collateral, and credit drawn over committed (an indirect measure of the cost of credit). Hence, procyclical bank capital regulation in good times contracts credit supply.

These findings are robust. For example, first, we apply the new provision formula to each bank's credit portfolio in 1998:Q4, well before any discussion on the policy had taken place, rather than in 2000:Q3, when dynamic provisioning became compulsory. Second, we exclude banks of direct interest to policy makers, that is, the savings or the very large banks, as policy makers capable of accurately predicting the heterogeneous changes in bank credit could have devised the formula to maximize its impact. Third, to allay any remaining endogeneity concerns, we exploit the opposite implications of the formula related to bank risk and also assess how unregulated foreign branches react as compared to what regulated foreign subsidiaries or domestic banks do. Fourth, to understand the economic channel, we analyze how credit responds to realized overall provisions instrumented with the formula-based provisioning. Fifth, by using firm observables, firm fixed effects, or no firm controls, we assess the degree to which the credit supply shock is orthogonal to observed and unobserved demand fundamentals.

tracted 3.7 percent in 2009 and the unemployment rate jumped to more than 25 percent. In 2010 Spain slightly came out of its recession but went back in from 2011 to 2013. In this regard Spain is indeed very well suited to test whether macroprudential instruments have an impact on the lending cycle and on real activity. In 1999 Spain had the lowest ratio of loan loss provisions to total loans among all OECD countries, but as a consequence of the introduction of dynamic provisioning, prior to the crisis in 2008 it was placed among the highest. 
But are firms really affected in good times? We find mostly not. Though total committed credit availability by firms drops immediately following the introduction of dynamic provisioning, three quarters after there is no discernible contraction of credit available to firms, as firms easily substitute credit from less affected banks (from both new banks and banks with an existing relationship). We consistently find no impact on firm total assets, employment, or survival.

Yet, while average firms are not significantly affected, there are important changes in the allocation of credit supply. After the policy shock, banks with higher requirements focus their credit supply more to firms with a higher ex ante interest paid and leverage, and with higher ex post default, thus suggesting that higher capital requirements may increase bank risk taking and searching for yield. This may be an unexpected but likely unintended consequence of this regulatory intervention (consistent with Koehn and Santomero [1980], Kim and Santomero [1988], Gale and Özgür [2005], and Gale [2010]). Moreover, the negative impact of higher requirements on credit is stronger for smaller firms and banks, which struggle more to absorb the shock.

In bad times things look very different. Banks with higher precrisis dynamic provision funds stemming from policy increase their supply of committed credit to the same firm permanently over the whole period 200910 (i.e., capital buffers mitigate the credit crunch). Similar findings hold for credit continuation, drawn and drawn over committed (i.e., implying a lower cost of credit), and again for numerous alterations in specification and instrumentation (as, e.g., instrumenting precrisis buffers with initial policy provisioning from 2000). Results moreover suggest that the mechanism works through saving capital in crisis times when profits and shareholder funds are scarce and costly. In addition, banks with dynamic provision funds below the ceiling (and hence that benefited most from the lowering of the floor in 2008:Q4 and in 2009:Q4 as they can immediately release capital funds) increase their credit supply only in the quarters around the policy changes. These banks also tighten maturity and collateral, possibly to compensate for the higher risk taken by easing volume.

Strikingly different in bad times (from good times) is that the changes in bank-firm-level credit are binding at the firm level; credit availability permanently contracts more for those firms that borrowed more from banks that when the crisis hit had lower dynamic provision funds stemming from policy. Results with granting of loan applications show that firms cannot substitute for lost bank financing. Consistent with this, we find that firm total employment and survival are negatively affected as well. The estimates also imply economical relevancy. Firms dealing with banks holding 1 percentage point more in dynamic provisioning funds (over loans) receive 9 percentage points more in committed credit than when dealing with other banks, have a 6 percentage point higher growth in the number 
of employees and a 1 percentage point higher likelihood of survival. In sum, banks with higher capital buffers, stemming from the stricter regulatory requirements in good times that can be drawn down in bad times, partly mitigate the deleterious impact of the financial crisis on the supply of credit and the associated real effects.

Compositional changes in credit supply are again important. Bank risk taking also differs between higher precrisis capital buffers and softer requirements on lowly capitalized banks. In the latter case more credit is supplied to more levered and longer-relationship firms, consistent with risk-shifting strategies related to zombie lending or gambling for resurrection. Hence, real and risk-taking effects are not the same when the regulator increases requirements in good times to have higher buffers in bad times than when she simply reduces them in bad times. Moreover, the positive effects on credit supply from countercyclical buffers are lower when bank nonperforming loans and leverage ratios are higher, thus suggesting a binding market constraint for weaker banks despite the policy softening.

Finally, we analyze the increase in provisions in 2012 that banks had to make on the basis of their lending exposure in 2011 to construction and real estate firms. The impact on credit supplied to firms not in construction or real estate is immediate and binding (again the granting of loan applications shows that credit substitution is difficult). These firms are subsequently negatively affected in their survival. Firms that dealt with banks that on average face 1 percentage point more tightening in requirements suffer a contraction of at least 4 percentage points in committed credit availability and 1 percentage point of survival. Significant effects arise only after the policy change and not before. Moreover, the credit crunch is softer by lowly capitalized banks with high nonperforming loan (NPL) ratios and for firms with worse credit history and profits, consistent with risk shifting by the banks more affected by the policy.

To conclude, responding to the urgent interest among policy makers and academics, ours is the first empirical paper to actually estimate the impact of a macroprudential policy on credit supply cycles and their associated real effects. The robust evidence shows that countercyclical bank capital buffers mitigate cycles in credit supply and have a positive effect on firm-level aggregate financing and performance. In bad times switching between banks is difficult; thus firms will be more affected by capital shocks. Hence, both the aggregate level of capital and its distribution across banks matter. Not only do policy constraints matter, but also market constraints as the results on bank NPLs and leverage suggest. Importantly, tightening capital requirements in bad times is much more contractive for credit and real output than it is in good times. Building up capital buffers before the crisis is superior in terms of maintaining real activity and avoiding risk shifting than changing requirements (for lowly capitalized banks) during the crisis, as the evidence from the floor reduc- 
tions in 2008-9 and the increase in 2012 suggest. However, a capital tightening in good times can induce both risk taking by regulated banks (which supply more credit to firms with higher both ex ante yield and leverage and ex post defaults) and regulatory arbitrage by nonregulated and regulated but less affected banks. ${ }^{7}$ Macroprudential policy can target the main sources of systemic risk as compared to monetary policy (Jiménez, Ongena, et al. 2014), but there can be regulatory arbitrage.

\section{Dynamic Provisioning, Data, and Identification Strategy}

\section{A. Dynamic Provisioning as a Countercyclical Tool}

Dynamic provisioning requirements in Spain are formula-based (Saurina 2009a). Total loan loss provisions for each quarter are the sum of (1) specific provisions based on the amount of nonperforming loans at each point in time plus (2) a general provision that is proportional to the amount of the increase in the loan portfolio plus, finally, (3) a general countercyclical provision element based on the comparison of the average of specific provisions along the last lending cycle (for the whole banking sector) with the current specific provision (for each individual bank). The per-period (the flow of) general provisions are computed as

General Provisions ${ }_{t}=\alpha \Delta$ Loans $_{t}+\left(\beta-\frac{\text { Specific Provisions }}{\text { Loans }_{t}}\right)$ Loans $_{t}$,

where Loans ${ }_{t}$ is the stock of loans at the end of period $t$ and $\Delta$ Loans $_{t}$ its variation from the end of period $t-1$ to the end of period $t$ (positive in a lending expansion, negative in a credit decline). The terms $\alpha$ and $\beta$ are parameters set by the Banco de España, the Spanish banking regulator; $\alpha$ is an estimate of the percentage of latent loss in the loan portfolio, while $\beta$ is the average along the cycle of specific provisions in relative terms. In good times, specific provisions are low-thus below the cycle average

\footnotetext{
${ }^{7}$ Differences with the bank capital literature are many: (1) We study policy changes that exogenously vary the regulatory capital requirements in good and bad times and the workings of countercyclical capital buffers when a crisis hits. In contrast, Peek and Rosengren (2000) exploit the negative shocks to the profitability of multinational banks. ChodorowReich (2014) focuses on credit during the crisis and employment outcomes for a reduced subset of firms. (2) We identify the supply of credit with loan-level data. Bernanke and Lown (1991) and Berger and Udell (1994) rely on macro- or bank-level data. (3) We assess the impact on bank-firm-level credit availability, maturity, collateralization, and cost and on firm-level financing and real performance. And (4) we analyze compositional changes in credit supply (notably on risk taking) and real effects for virtually all firms in the economy. Both risk taking and the externalities to the real sector may be more important for financial stability than the topics dealt with in the bank capital literature so far.
} 
$\beta$ - and hence flows are positive, thus increasing the buffer. By the same reasoning, in bad times, flows will be negative, thus allowing the countercyclical buffer to be used. Therefore, the second term of the formula is the key countercyclical component.

The above formula is a simplification. There are six homogeneous risk buckets to take into account the different nature of the distinct segments of the credit market, each of them with a different $\alpha$ and $\beta$ parameter that is increasing in risk levels, calibrated on the basis of the previous credit cycle. Consumer credit is put in the highest risk bucket, business loans and mortgages are in intermediate ones, and public debt is in the lowest risk bucket. Moreover, there is a ceiling for the fund of general loan loss provisions fixed at 125 percent of the product of parameter $\alpha$ and the total volume of credit exposures (i.e., 125 percent of the latent loss of the loan portfolio). The objective is to avoid an excess of provisioning, which might occur in a very long expansionary phase as specific provisions remain below the $\beta$ component.

There was also a minimum floor value for the fund of general provisions at 33 percent of the latent loss. This minimum was lowered in 2008:Q4 to 10 percent and in 2009:Q4 to 0 percent in order to allow for more usage of the general provisions previously built in the expansionary period (we study both events later). ${ }^{8}$ Banks are also required to publish the amount of their dynamic provision each quarter. Moreover, in case of liquidation of a bank, general provisions correspond to shareholders. Therefore, as dynamic provisions (as said) are a special kind of general loan loss provision, the buffer they accumulate in the expansion phase can be assimilated to a capital buffer. From 2005 onward, dynamic provisions were also formally considered to be tier 2 capital (regulatory capital, although not as core as equity).

Figure 1 shows over time the flow of total net loan provisions (panel A), the stock of NPLs over total loans (panel B), and the stocks of total, specific, and general dynamic provisions over total loans (panel C), highlighting the introduction in July 2000, the reduction in 2005, and the increase during the crisis (we analyze all shocks indicated by dashed vertical lines in fig. 1). So then why would dynamic provisioning and the resultant countercyclical capital buffers be beneficial for the economy? First note that in panel $\mathrm{C}$ total provisions grow at a substantially lower speed than specific provisions in crisis times because dynamic provisioning funds are reduced (flows are negative so the stock is reduced). This implies that ex-

\footnotetext{
${ }^{8}$ Banks for which the formula states that their provision funds should be higher than the ceiling can have provision funds at the ceiling, but-because of the higher formula value - in crisis times they cannot release funds as fast as banks with theoretical values below the ceiling. See also Fernández de Lis, Martínez Pagés, and Saurina (2000) and Banco de España (2004).
} 


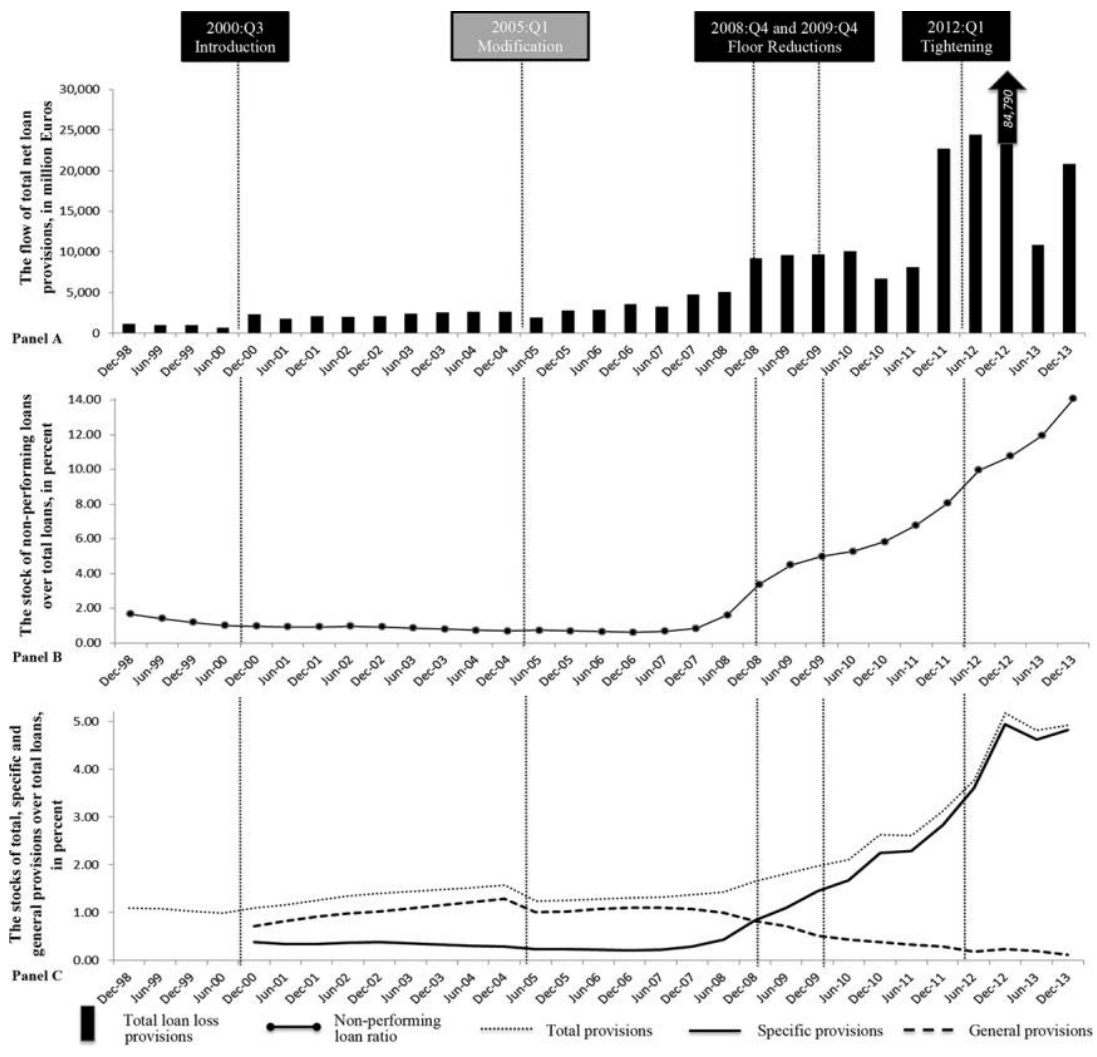

FIG. 1.- The flow of total net loan loss provisions, in euros, and the stocks of nonperforming loans and total, specific, and general loan provisions over total loans, in percent.

actly at the time when bank profits are very low or even negative and access to equity funds costly, banks can draw down the buffers that were built up in good times. These buffers should therefore reduce the costs (and increase the quantity) of financing for banks, which they could pass on to their borrowers. Indeed, Laeven and Majnoni (2003) find that in most countries, banks' total provisioning occurred mostly in crisis times, and they conjecture that this will magnify the procyclicality of bank lending. Dynamic provisioning by building the buffers in good times could help to reduce the credit crunch in bad times.

Note also that in 2010 the speeds of total provisions and specific provisions are very similar (i.e., identical slopes) because at that time the dynamic provisioning funds are almost depleted. The crisis shock was very large as compared to the relatively small ex ante buffer of dynamic provisions the banks had in place (approximately 1 percent of total assets and 84 percent of total provisions in 2007:Q4), so these provisions were al- 
most depleted by the end of 2010 (only 11 percent of total provisions in 2010:Q4 remained). Finally, given that the dynamic provision funds were depleted, in 2012 the new government increased provisioning on the basis of real estate exposure in a one-off movement to clean up banks' balance sheets.

\section{B. Data Sets}

Spain offers an ideal experimental setting for identification; not only because of the policy experiments with dynamic provisioning, but also since its economic system is bank dominated and its exhaustive but confidential credit register, called CIR (which is used by the Banco de España for supervision), records all bank lending activity over the last full credit cycle matched with firm and bank balance sheet data (Jiménez, Mian, et al. 2014). We work with commercial and industrial (C\&I) loans granted by commercial banks, savings banks, and credit cooperatives (representing almost the entire Spanish banking system) to nonfinancial publicly limited and limited liability companies. We use all C\&I loans (covering 80 percent of total loans) granted by more than 175 banks to 100,000 firms. The CIR is almost comprehensive, as the monthly reporting threshold for a loan is only $€ 6,000$, which alleviates any concerns about unobserved changes in bank credit to small and medium-sized enterprises. We also use loan application-level data to analyze credit substitution in the extensive margin (Jiménez, Ongena, et al. 2014).

We match each loan to bank balance sheet variables (size, capital, liquidity, NPLs, profits, real estate exposure, and other key variables as explained in the next sections) and to selected firm variables (firm identity, industry, location, size, age, capital, liquidity, profits, tangible assets, and whether or not the firm survives). We also analyze the loans that cannot be matched to firm variables. Both loan and bank data are owned by the Banco de España in its role of supervisor (the data are confidential, but the results of the paper can be replicated; see the online appendix for details). The firms' data set is available from the Spanish Mercantile Register at a yearly frequency (and represents around 70 percent of outstanding bank loans from the CIR, though we lose 30 percent more when analyzing firm employment). Firm survival data come from the Central Business Register (DIRCE). Firm balance sheet data are available until 2011:Q4, whereas survival is available until 2012:Q4 and loan and bank-level data are available until 2013:Q3.

\section{Identification Strategy}

We study the impact of the policy experiments regarding dynamic provisioning on credit availability at both loan and firm levels and the associ- 
ated firm-level real effects. As the dynamic provisioning formula is based on different risk buckets that depend on the loan portfolio and banks differ in their lending, banks face different provisioning requirements from the policy changes. We explain each shock and specification we run in detail in Sections III and IV. For each shock we calculate the changes in each bank's provisioning requirement. As the policy shocks across banks cannot be considered "random," the data and empirical strategy are crucial. We perform a difference-in-difference analysis in which we compare the lending of the same bank before and after each shock and simultaneously compare it to other banks differently affected by the shock; the identification comes both from the timing (before and after the shock) and from the shocks that affected banks differentially.

Even though we analyze the same bank before and after the shock (which is similar to including bank fixed effects), we also need to control for bank fundamentals that could be differently affected. First, borrowers may differ, and we analyze the change in credit availability to the same firm at the same time by banks with different treatment intensity to each shock by using firm or firm-time fixed effects in loan-level regressions (Khwaja and Mian 2008). In this way, we capture both observed and unobserved time-varying heterogeneity in firm fundamentals (i.e., credit demand and, as firms often engage similar banks, also the characteristics of the bank's portfolio composition). Second, we analyze whether the estimated coefficient is different from the one estimated in a regression without firm fixed effects (and even without any firm variables) to analyze whether the policy shock is orthogonal to borrowers' demand and thus whether firm-level regressions with only firm observables yield any implications for credit availability (Jiménez, Mian, et al. 2014). Third, in robustness we control for up to 32 bank variables covering all relevant characteristics of banks and include bank-firm and loan variables (as loans by different banks to the same firm could be different).

To address any remaining endogeneity concerns, we further exclude either the savings banks or the very large banks as policy makers could have devised the formula to maximize the credit impact at either one of these groups of banks, instrument dynamic provisioning in each experiment with pertinent formula-determined prior values, and add bank fixed effects in cross-sectional specifications that assess the compositional changes in credit supply. And while domestic banks and foreign subsidiaries were subject to dynamic provision requirements, foreign branches were not (foreign branches have to report all loans to the CIR but are not regulated in their capital and accounting in Spain). We therefore assess these two groups of treated versus nontreated banks in their lending to the same firm at the same time. We also analyze foreign subsidiaries versus branches. Moreover, we exploit the opposite implications of the formula related to higher bank risk to check whether it is the policy (formula) 
or risk driving the results. Finally, we analyze the changes in credit on the changes in realized overall bank provisions, which is instrumented in a first stage with the deterministic formula-based provisioning.

\section{In Good Times: Introduction of Dynamic Provisioning}

\section{A. The Specifics of the Introduction of Dynamic Provisioning in 2000:Q3}

Dynamic provisioning was introduced in Spain in July 2000 and enforced at the end of September 2000 (our first policy experiment), as Spain had very low levels of provisioning compared to the rest of the OECD countries. We apply the provisioning formula that is introduced to the existing loan portfolio in 1998:Q4 (except for the consumer credit component as we do not have the individual loans), without taking into account the specific provision component to avoid endogeneity, yielding a bank-specific amount of new funds that is expected to be provisioned. We then scale this amount by the bank's total assets. We label this scaled amount in provisions for bank $b$, dynamic provision (for 1998:Q4) ${ }_{b}$, abbreviated in interaction terms by $\mathrm{DP}_{b}$ (table $\mathrm{A} 1$ collects all variable definitions). We go back 2 years to avoid self-selection problems, that is, banks changing their credit portfolio weights before the law enters into force.

The summary statistics in table 1 show that there is ample variation in the dynamic provisions (over total assets) that banks have to make. The mean of the banks' dynamic provision is 0.26 percent, its median 0.22 , and the standard deviation 0.10 , ranging from a maximum of 0.86 to a minimum value of 0 percent. Not reported is how dynamic provision varies across banks' characteristics. Banks with a lower liquidity ratio were facing higher dynamic provisioning, and so were commercial banks (more than savings banks and cooperatives). In addition, banks that had to provision more did not decrease tier 1 capital. Moreover, regressing dynamic provision on firm observables implies the following: When no controls are included, less capitalized and smaller firms are more likely to work with less affected banks; when only firm province and industry fixed effects are added as controls, all the firm variables are insignificant.

\section{B. Loan-Level Results}

The first model at the loan level we estimate is

$\Delta \log$ Commitment (2000:Q1-2001:Q2) $)_{b f}$

$$
\left.=\delta_{f}+\beta \text { Dynamic Provision (for 1998:Q4) }\right)_{b}+\operatorname{controls}_{b f}+\varepsilon_{b f} \text {, }
$$


where $\Delta \log$ Commitment $_{b f}$ is the change in the logarithm of (strictly positive) committed credit by bank $b$ to firm $f$ over the impact period from 2000:Q1 to 2001:Q2, $\delta_{f}$ are firm fixed effects, and controls ${ }_{b f}$ can include other bank and bank-firm relationship characteristics, which comprise ln(Total Assets), Capital Ratio, Liquidity Ratio, Return on Assets (ROA), Doubtful Ratio, in addition to Commercial Bank and Savings Bank dummies, and $\ln (1+$ Number of Months with the Bank $) ;{ }^{9} \varepsilon_{b f}$ is the error term and $\beta$ the main coefficient of interest. This model will be estimated for a sample of 416,611 observations from bank-firm pairs of firms with multiple bank-firm relationships. Standard errors are clustered at the bank and firm level (clustering at the bank level yields virtually identical results). We also estimate this model for different lending margins and assess quarter by quarter outcomes (to test for pretrends and short- and medium-term policy effects). And in robustness we vary controls and subsamples.

The estimated coefficient on Dynamic Provision in model 1 in table 2, which equals $-0.357^{* * *}$, is both statistically significant and economically relevant. A one standard deviation increase in Dynamic Provision (i.e., 0.10 percent) relatively cuts committed lending by 4 percentage points. That is a sizable effect, as committed lending on the intensive margin contracted by 2 percent on average from 2000:Q1 to 2001:Q2. Next we add firm $\times$ bank type (i.e., commercial, savings, and other banks) fixed effects in model 2 (limiting the used sample to firms that borrow from multiple banks of the same type) and then loan characteristics in model 3. The coefficients on Dynamic Provision equal $-0.397^{* * *}$ and $-0.335^{* * *}$, respectively. Results remain virtually unaffected if we add to the parsimonious set of controls the following five additional bank characteristics that proxy for bank risk taking: Loans to Deposits Ratio, Construction, Real Estate, and Mortgages over Total Assets, Net Interbank Position over Total Assets, Securitized Assets over Total Assets, and the Regulatory Capital Ratio. The estimated coefficient (untabulated) then equals $-0.305^{* * *}$. Adding squared and cubed terms of all bank characteristics (in total 32 terms) leaves the estimate of the coefficient on Dynamic Provision again mostly unaffected (i.e., $-0.328^{* *}$ ). Moreover, when none of the firm characteristics (i.e., firm fixed effects, province and industry fixed effects, firm variables) are included in the specification, the estimated coefficient then equals $-0.290^{* *}$, which is statistically not different from the estimate obtained with firm fixed effects in model 1 (i.e., $-0.357^{* *}$ ). Therefore, re-

${ }^{9}$ The change in credit is from one quarter before the policy was announced over a period of 1 year afterward and is winsorized (and also the below-introduced $\Delta \log$ Drawn) at the 1 st and 99 th percentiles. 


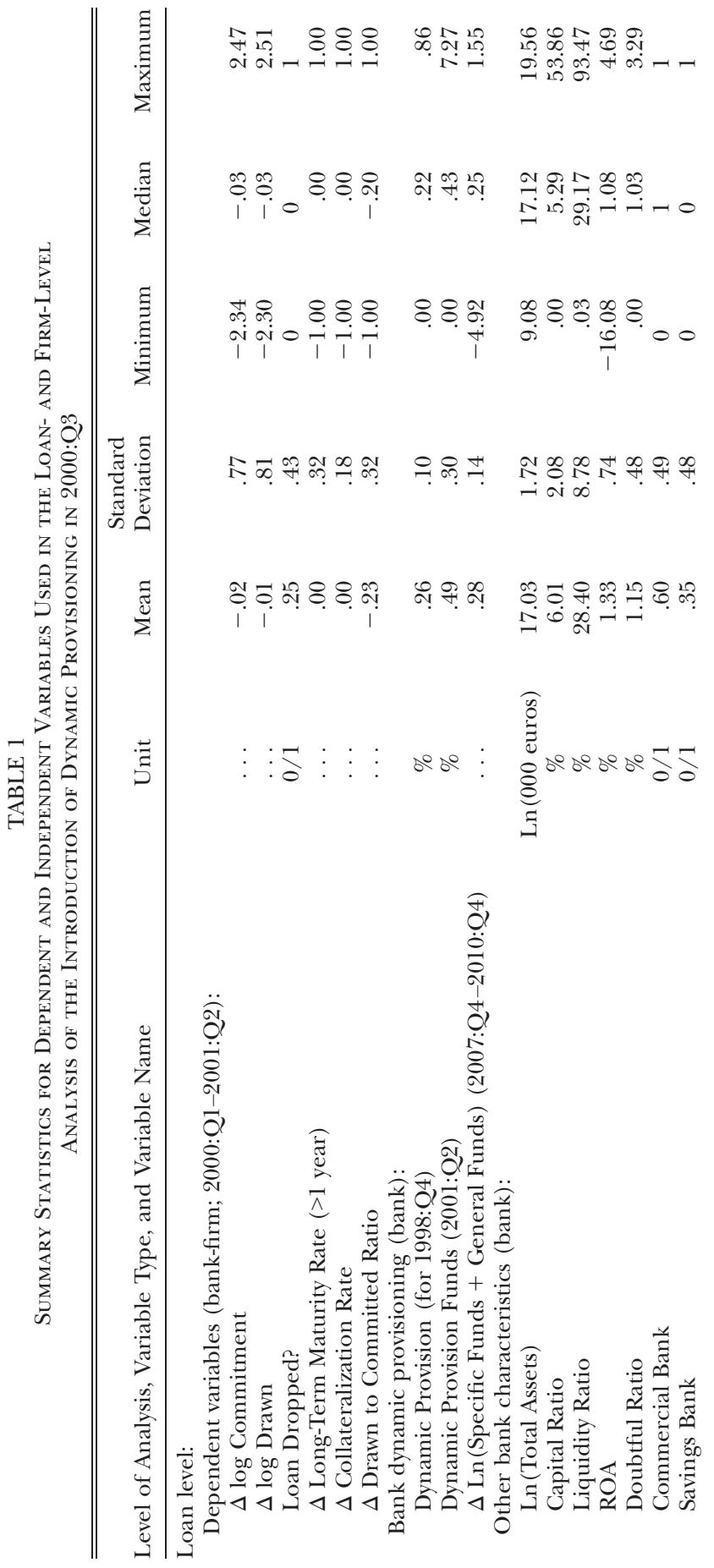




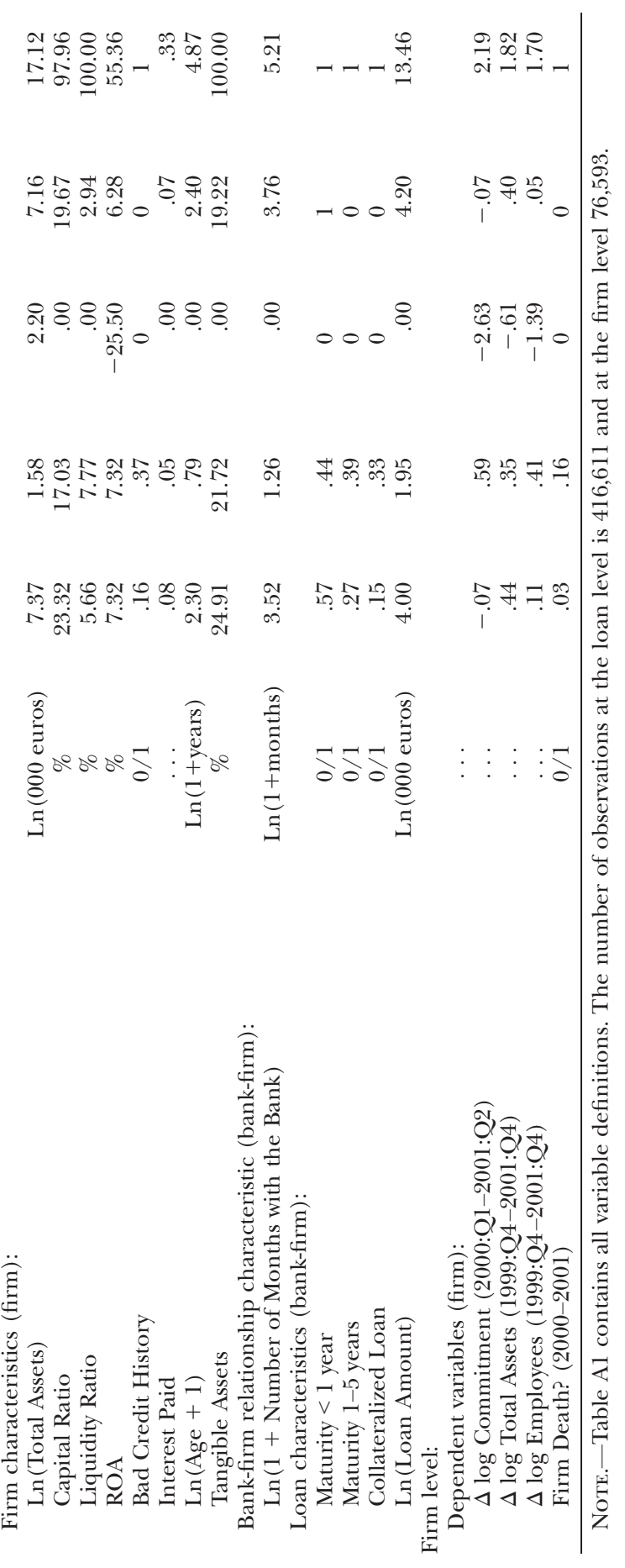

2141

This content downloaded from 084.089.157.043 on April 09, 2019 09:14:29 AM All use subject to University of Chicago Press Terms and Conditions (http://www.journals.uchicago.edu/t-and-c). 


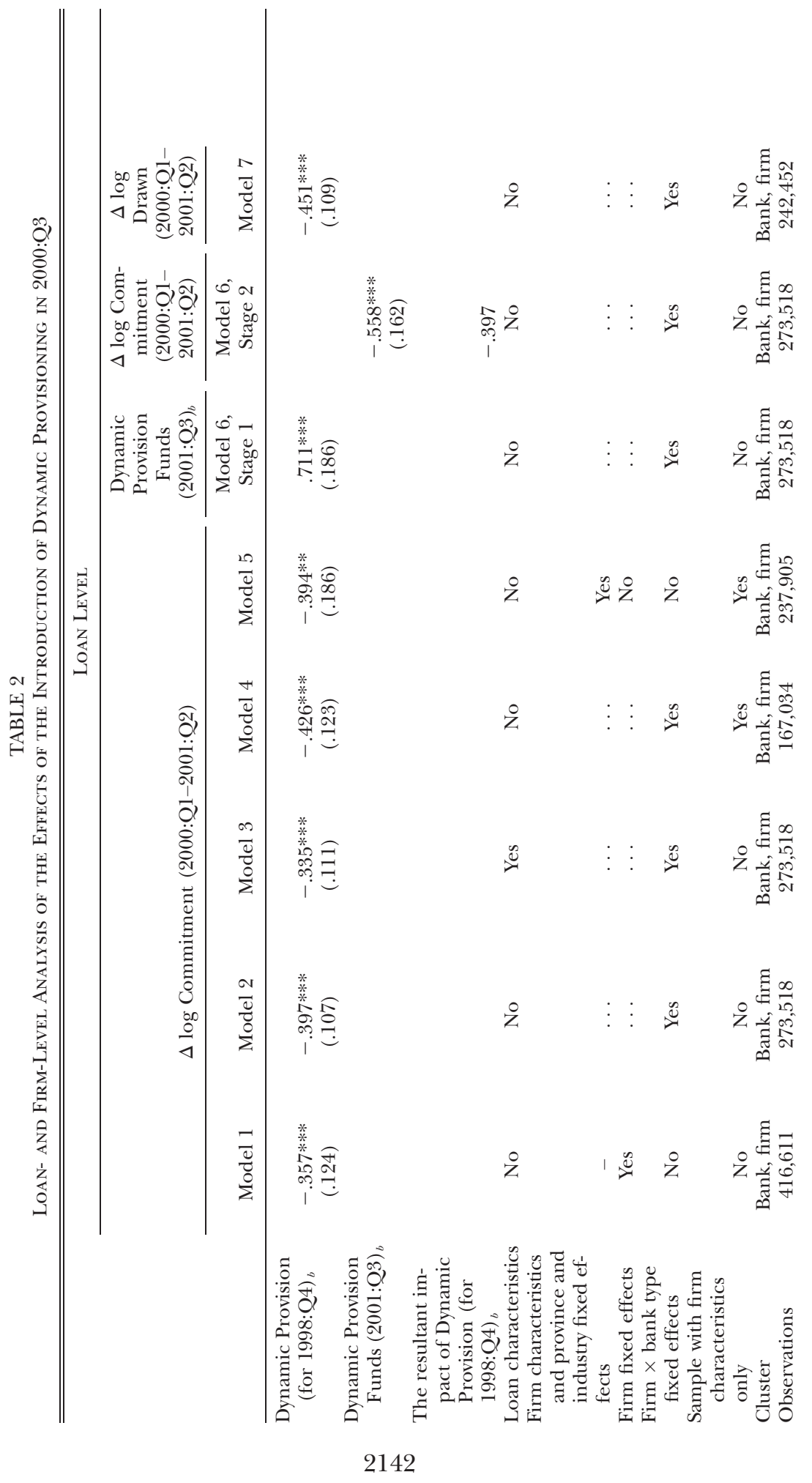

This content downloaded from 084.089.157.043 on April 09, 2019 09:14:29 AM 


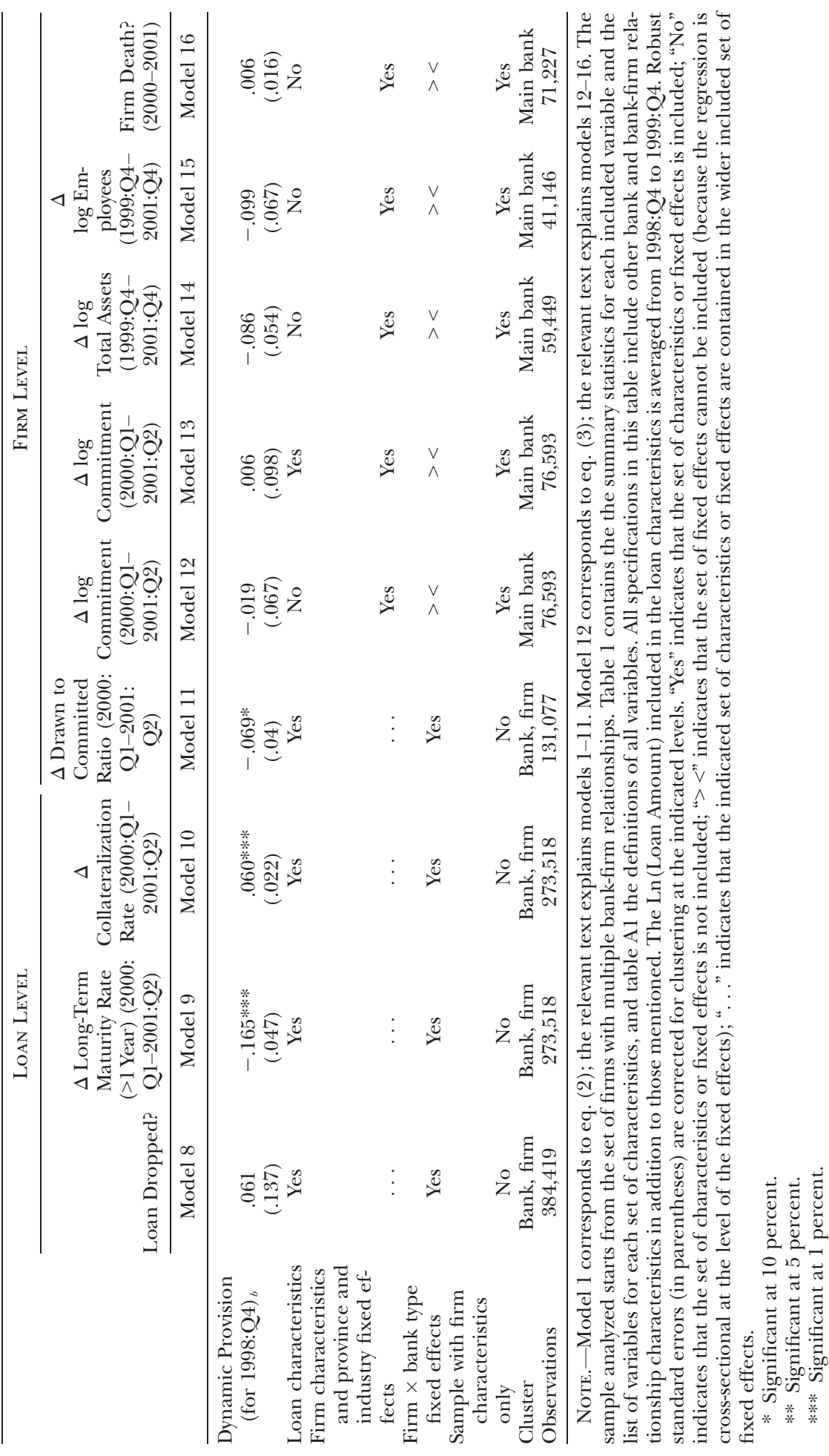

2143

This content downloaded from 084.089.157.043 on April 09, 2019 09:14:29 AM 
sults suggest that the policy shock is orthogonal to firm fundamentals (demand). All these robustness checks will also be done for the benchmark models that we present later, but given their very limited impact (also then), these will not be mentioned further.

In models 4 and 5 we restrict the sample to loans that can be matched to key firm variables to make an adequate comparison with the firm-level specifications (where we use only firm observables). For the same reason we replace the saturating set of firm $\times$ bank type fixed effects by firm variables and province and industry fixed effects in model 5. Despite these changes, the coefficients on Dynamic Provision remain very similar, which further suggests that the policy shock is orthogonal to demand.

Figure 2 displays with a black line the estimated coefficient on Dynamic Provision for model 4 when altering the time period over which $\Delta \log$ Commitment is calculated, that is, from 2000:Q1 to the quarter displayed on the horizontal axis (starting in 1999:Q1 and finishing in 2003:Q4). The dashed black lines indicate a 10 percent confidence interval. This figure (and similar later figures) comprises more than what is in table 2, showing the main result over time for each single quarter before and after the 2000 shock. The estimated coefficient is statistically significant in 2000: Q2 when dynamic provisioning was announced and turns also economically more relevant in 2000:Q3, when it started to be enforced (this lack of any significant preshock trend in the estimated coefficients is consistent with unreported simple plots indicating that banks made additional provisions only after the policy introduction; see also fig. 1). In sum, banks with higher dynamic provisions cut their total credit commitment more to the same firm at the same time after the policy shock (as compared to before the shock) than banks with lower dynamic provisioning requirements.

To further allay endogeneity concerns, we also analyze the difference between those banks that are and those that are not subject to dynamic provision requirements in Spain. The regulated banks are the domestic banks and the foreign bank subsidiaries, while the foreign bank branches were not regulated in this regard and hence not affected. We perform such an analysis in a difference-in-difference setting with either a dummy variable (regulated or not; upper panel in fig. 3) or a continuous variable (equal to zero if not regulated and, if the bank was regulated, by how it had to increase provisioning based on the formula; not reported). We again include firm fixed effects for each quarter. The estimates confirm that affected banks contract lending. We also study the group of few foreign banks by itself, leaving us with a substantially reduced sample, and also find stronger effects for banks that are regulated (and that increase dynamic provisions) than those that are not (see the lower panel in fig. 3). Also, to further allay endogeneity concerns, when we exclude for robustness 


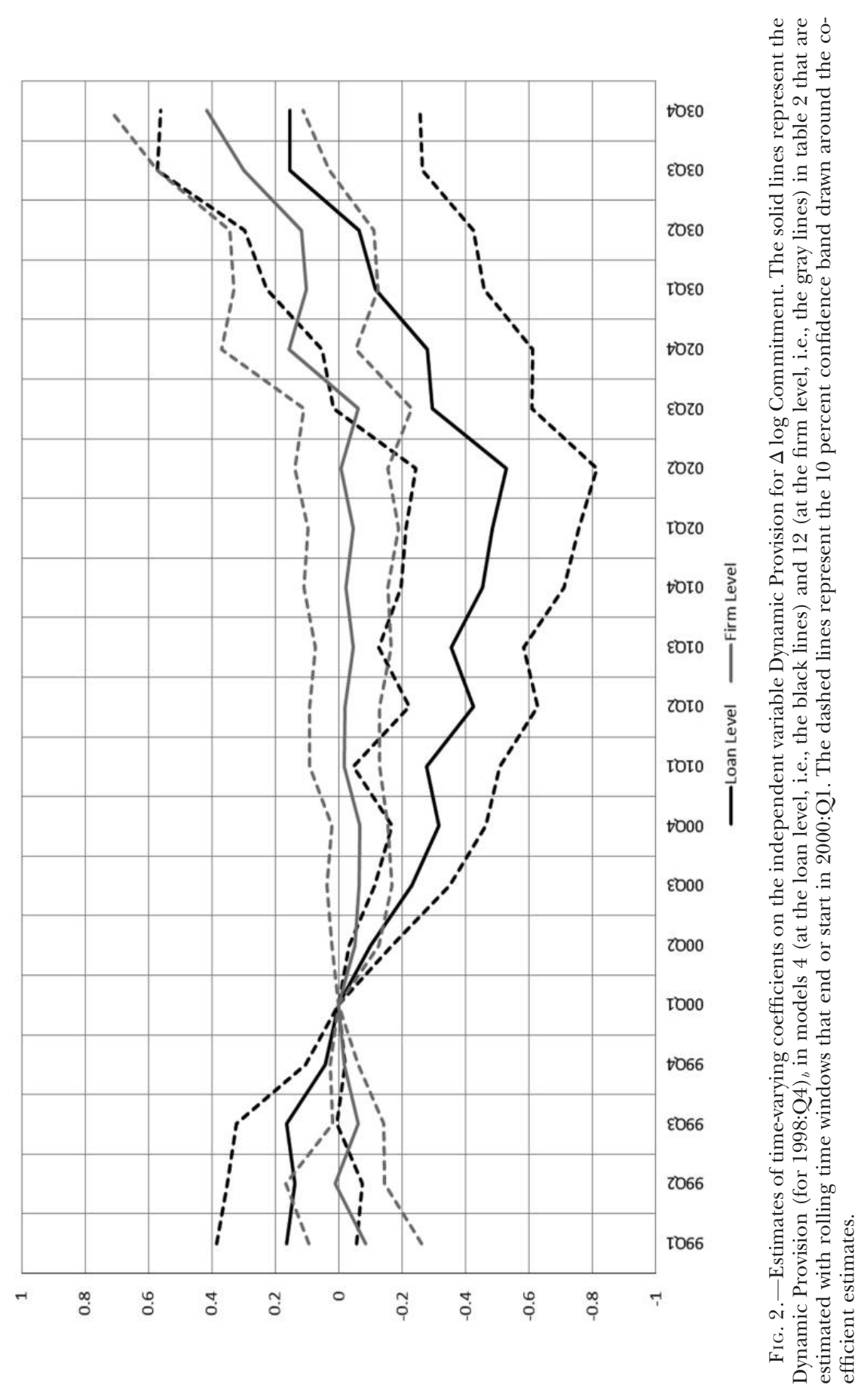

This content downloaded from 084.089.157.043 on April 09, 2019 09:14:29 AM

All use subject to University of Chicago Press Terms and Conditions (http://www.journals.uchicago.edu/t-and-c). 

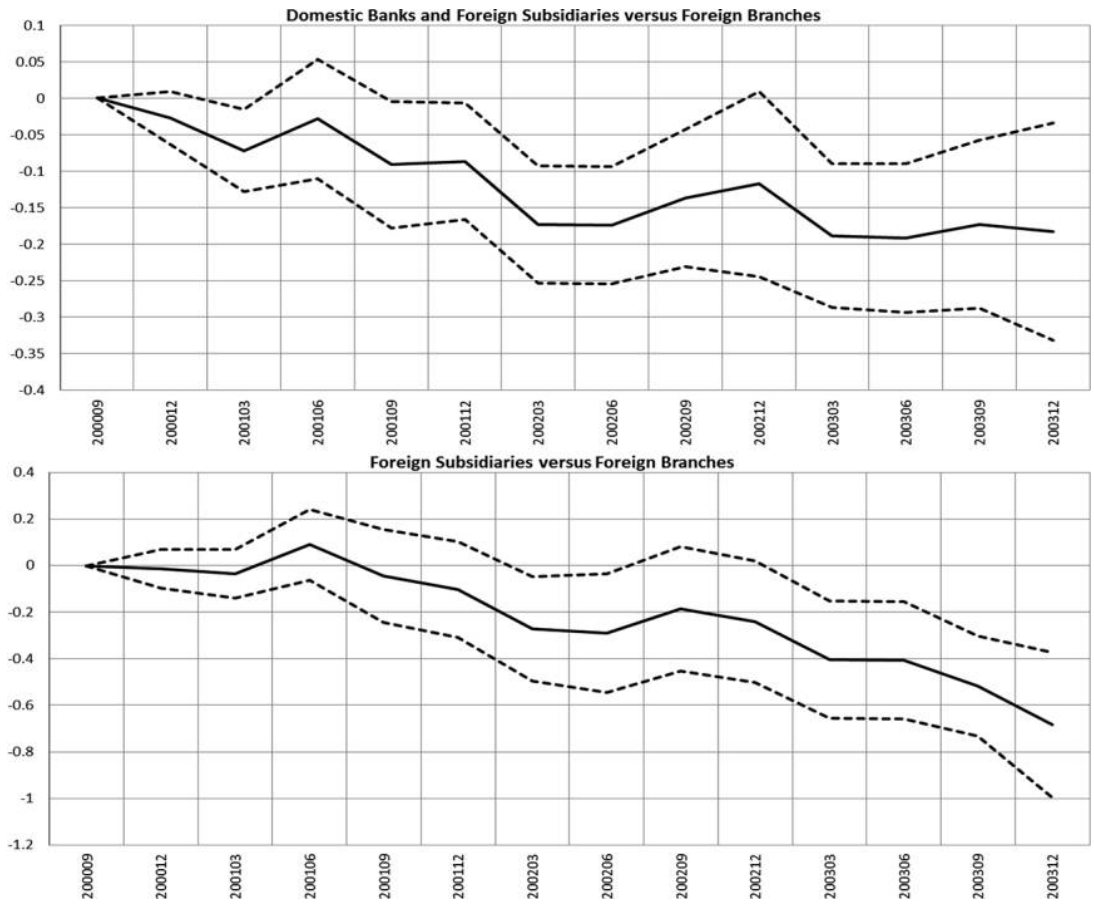

FIG. 3.-Estimates of time-varying coefficients on the indicated groups of banks for $\Delta \log$ Commitment. The solid lines represent the estimated coefficients on the following two variables that replace Dynamic Provision (for 1998:Q4) ${ }_{b}$ in two models that are equivalent to model 1 in table 2: in the model displayed in the upper panel a dummy that equals one if the bank granting the loan is a domestic bank or a subsidiary of a foreign bank and that equals zero otherwise; and in the model displayed in the lower panel, a dummy that equals one if the bank granting the loan is a subsidiary of a foreign bank and that equals zero otherwise. In the latter case the sample is restricted to the loans that are granted by either subsidiaries or branches of foreign banks. In both cases the coefficients are estimated with rolling time windows that start over the 2000:Q1-2000:Q3 period. The dashed lines represent the 10 percent confidence band drawn around the coefficient estimates.

the savings or the very large banks, the estimated coefficients are very similar. ${ }^{10}$

${ }^{10}$ The dynamic provisioning formula treats opposite risk stemming from buckets and from current specific provisions, where the first one increases the dynamic provisions and the second one does not. To investigate this issue, we split both dynamic provisioning credit categories and specific provision into two risk classes for each bank, high and low. Consequently, we have four different coefficients on dynamic provisioning: $\beta \mathrm{HH}, \beta \mathrm{HL}, \beta \mathrm{LH}$, and $\beta \mathrm{LL}$ (the first capital letter indicating the category of dynamic provisioning, the second the level of the specific provision). We expect $\beta \mathrm{HL} \leq \beta \mathrm{HH} \leq \beta \mathrm{LH}$ and $\beta \mathrm{HL} \leq \beta \mathrm{LL} \leq \beta \mathrm{LH}$ (recall that $\beta$ is expected to be negative, so that the absolute value of $\beta$ HL should be the highest). Excluding $\beta \mathrm{LH}$ from the estimation, we obtain the estimated coefficients of $\beta \mathrm{HL}$ (equal to $-0.23^{* * *}$ ), $\beta \mathrm{HH}$ (equal to $-0.061^{*}$ ), and $\beta \mathrm{LL}$ (equal to -0.034 ); results are not further tabulated. These results imply that it is the "formula" (i.e., the tightening of dynamic provisioning requirements - and not bank risk per se) that affects credit supply 
In model 6 we replace Dynamic Provision (1998:Q4) with the Dynamic Provision Funds in 2001:Q3, which is the level of dynamic provisioning actually chosen by the bank during the impact period, instrumented with the until now employed and formula-determined Dynamic Provision (1998:Q4). The estimated coefficient in the first stage equals $0.711^{* * * *}$ (the instrument does not suffer from a weak instrument problem), while the estimated coefficient from the second stage equals $-0.558^{* * *}$, which implies an impact of Dynamic Provision (1998:Q4) on lending of -0.397 $(=0.711 \times-0.558)$, which is very similar to the one-stage coefficient estimates.

Finally, we turn to a two-stage model that allows the effect of changes in dynamic provisioning in lending to go through the changes in the specific and general funds. For organizational clarity we display the estimates in model 1 of a new table 3 (which will be augmented with very similar exercises from the other shocks). The changes in Dynamic Provision (1998: Q4) have an almost one-for-one effect in terms of the changes in the specific and general funds. The estimated coefficient equals $0.930^{* * *}$ (again the instrument does not suffer from a weak instrument problem). The changes in those funds then result in committed lending with an estimated coefficient of $-0.427^{* * *}$, for an overall impact of dynamic provisioning of $-0.397(=0.930 \times-0.427)$. Hence, dynamic provisioning by increasing overall provisions reduces credit supply.

Models 7-11 in table 2 show that after the introduction of dynamic provisioning, banks also tighten credit drawn (though it is potentially firm demand driven), maturity, collateralization, continuation, and credit drawn over committed (which reflects cost of credit given that firms with at least two credit lines will in general draw more after the shock from banks with cheaper credit). Hence, banks tighten all credit supply terms. ${ }^{11}$

Next we investigate heterogeneous effects across bank and firms. Table 4 tabulates the benchmark specifications that also include interactions of dynamic provision with lagged (a) bank total assets, capital ratio, ROA, and nonperforming loan ratio; (b) firm total assets, capital ratio, ROA, bad credit history, interest paid, and ex post default; and $(c)$ the length of the bank-firm relationship. Results indicate that dynamic provisioning cuts committed credit more at smaller banks and for smaller

after the introduction of the policy. We obtain the same result if in our benchmark model we introduce the specific provision for the bank and its interaction with dynamic provisioning (DP). We then find that the coefficients on dynamic provisioning itself are $-0.468^{* * *}$ and 41.538 * for its interaction with the specific provision, implying that a more severe tightening of requirements results in a lowering of the credit supply, but the effects are mitigated if the bank already has in place higher ex ante specific provisions.

${ }^{11}$ Dynamic Provision is statistically significant on Loan Dropped? for an impact period extending past 2002:Q3 (not reported), because if loans with a long maturity are not repaid, the dependent variable is zero. 


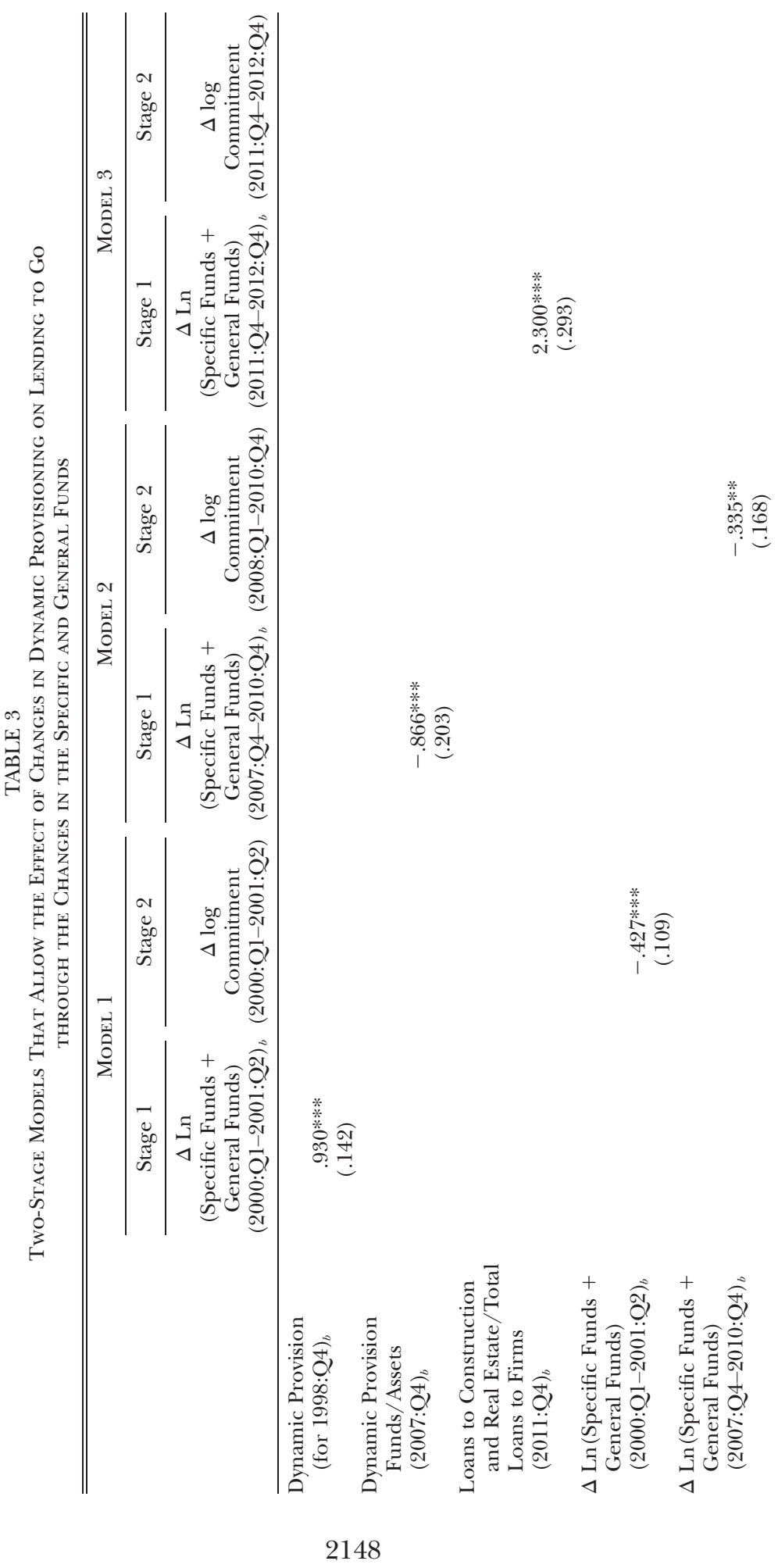

This content downloaded from 084.089.157.043 on April 09, 2019 09:14:29 AM 


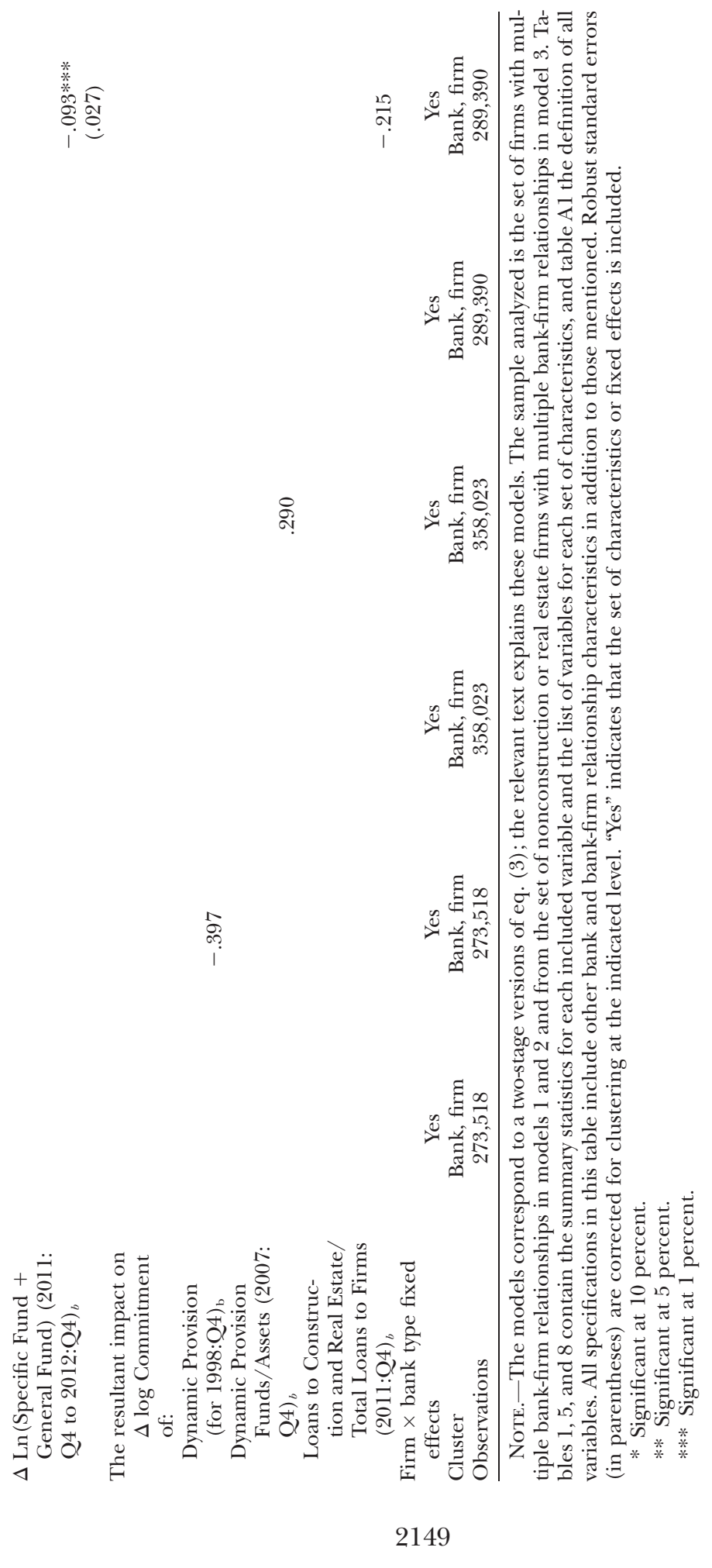

This content downloaded from 084.089.157.043 on April 09, 2019 09:14:29 AM All use subject to University of Chicago Press Terms and Conditions (http://www.journals.uchicago.edu/t-and-c). 
TABLE 4

Analysis of the Changes in Committed Lending at the Introduction of Dynamic Provisioning in 2000:Q3 across Banks and Firms

\begin{tabular}{|c|c|c|c|c|c|}
\hline & Model 1 & Model 2 & Model 3 & Model 4 & Model 5 \\
\hline $\begin{array}{l}\text { Dynamic Provision } \\
\quad(\text { for 1998:Q4) })_{b}\left(=\mathrm{DP}_{b}\right)\end{array}$ & $\begin{array}{l}-.987 * * * \\
(.199)\end{array}$ & & & & \\
\hline $\mathrm{DP}_{b} \times \operatorname{Ln}($ Total Assets $)$ & $\begin{array}{l}.302 * * * \\
(.061)\end{array}$ & & & & \\
\hline $\mathrm{DP}_{b} \times$ Capital Ratio $b$ & $\begin{aligned}-.046 \\
(.045)\end{aligned}$ & & & & \\
\hline $\mathrm{DP}_{b} \times \mathrm{ROA}_{b}$ & $\begin{array}{c}-.067 \\
(.109)\end{array}$ & & & & \\
\hline $\mathrm{DP}_{b} \times$ Doubtful Ratio $_{b}$ & $\begin{array}{c}-.222 \\
(.19)\end{array}$ & & & & \\
\hline $\mathrm{DP}_{b} \times \operatorname{Ln}($ Total Assets $f)$ & $\begin{array}{l}.111 * * * \\
(.037)\end{array}$ & $\begin{array}{l}.115^{* * * *} \\
(.038)\end{array}$ & & $\begin{array}{l}.061 * * \\
(.028)\end{array}$ & $\begin{array}{l}.115^{* * * *} \\
(.038)\end{array}$ \\
\hline $\mathrm{DP}_{b} \times$ Capital Ratio ${ }_{f}$ & $\begin{array}{l}-.010 * * * \\
(.003)\end{array}$ & $\begin{array}{l}-.010 * * * \\
(.003)\end{array}$ & & $\begin{array}{l}-.008^{* * * *} \\
(.002)\end{array}$ & $\begin{array}{l}-.010 * * * \\
(.003)\end{array}$ \\
\hline $\mathrm{DP}_{b} \times \mathrm{ROA}_{f}$ & $\begin{array}{l}-.004 \\
(.005)\end{array}$ & $\begin{array}{l}-.004 \\
(.005)\end{array}$ & & $\begin{array}{l}.000 \\
(.003)\end{array}$ & $\begin{array}{c}-.004 \\
(.005)\end{array}$ \\
\hline $\mathrm{DP}_{b} \times$ Bad Credit History ${ }_{f}$ & $\begin{array}{l}-.135 \\
(.086)\end{array}$ & $\begin{array}{l}-.139 \\
(.087)\end{array}$ & $\begin{array}{l}.031 \\
(.053)\end{array}$ & $\begin{array}{c}-.029 \\
(.073)\end{array}$ & $\begin{array}{c}-.129 \\
(.09)\end{array}$ \\
\hline $\mathrm{DP}_{b} \times$ Interest Paid $_{f}$ & $\begin{array}{l}1.300 * * \\
(.557)\end{array}$ & $\begin{array}{l}1.309 * * \\
(.559)\end{array}$ & & & $\begin{array}{l}1.280 * * \\
(.56)\end{array}$ \\
\hline $\mathrm{DP}_{b} \times$ Future Default $(2001-5)_{f}$ & & & $\begin{array}{l}.255^{* * *} \\
(.073)\end{array}$ & $\begin{array}{l}.145^{* *} \\
(.071)\end{array}$ & $\begin{array}{l}.068 \\
(.079)\end{array}$ \\
\hline $\begin{array}{l}\mathrm{DP}_{b} \times \operatorname{Ln}(1+\text { Number of } \\
\text { Months with the Bank })_{b f}\end{array}$ & $\begin{array}{l}-.009 \\
(.035)\end{array}$ & $\begin{array}{l}-.020 \\
(.035)\end{array}$ & $\begin{array}{c}-.033 \\
(.038)\end{array}$ & $\begin{array}{r}-.047 \\
(.037)\end{array}$ & $\begin{aligned}-.019 \\
(.035)\end{aligned}$ \\
\hline Firm $\times$ bank type fixed effects & Yes & Yes & Yes & Yes & Yes \\
\hline Bank fixed effects & No & Yes & Yes & Yes & Yes \\
\hline Cluster & Bank, firm & Bank, firm & Bank, firm & Bank, firm & Bank, firm \\
\hline Observations & 77,483 & 77,483 & 77,483 & 77,483 & 77,483 \\
\hline
\end{tabular}

Note.-The dependent variable is $\Delta \log$ Commitment (2000:Q1-2001:Q2). The sample analyzed is the set of firms with multiple bank-firm relationships and firm characteristics. Table Al contains all variable definitions. All specifications in this table include other bank and bank-firm relationship characteristics in addition to those mentioned. Robust standard errors (in parentheses) are corrected for clustering at the indicated level. "Yes" indicates that the set of characteristics or fixed effects is included; "No" indicates that the set of characteristics or fixed effects is not included.

* Significant at 10 percent.

** Significant at 5 percent.

*** Significant at 1 percent.

firms. Interestingly, ex ante more levered firms and those that yield a higher interest rate paid to the banks are less affected by credit supply restrictions from more affected banks, maybe because these banks take on higher risk to compensate for their increase in the cost of capital and the lowering of bank profits (in line with some theoretical predictions) or because of their higher policy capital buffers. Moreover, the reduction in credit supply by banks with higher dynamic provisioning is lower to firms that default more ex post. This result is significant only if we do not con- 
trol for the interaction of provisioning and ex ante firm yield, but the coefficients on the interaction with yield and leverage remain similar in size and significant. This suggests not only that banks with higher dynamic provisioning steer more credit to firms with higher yield, leverage, and default but also that ex ante yield and leverage captures well ex post default.

All in all, these findings are consistent with a search for yield by the banks triggered by the introduction of dynamic provisioning. An important caveat is that banks are not price takers in their lending as compared to investing in bonds from large corporations or countries, as, for example, banks could have some monopolistic power in lending; though all the results are very similar, or even stronger, if we restrict the loans for each firm to the banks that are not its main lender. Finally, in model 2 in table 4 we add bank fixed effects, and results are virtually unaffected, suggesting that unobserved bank heterogeneity is unlikely to account for the variation in credit supply observed.

\section{Firm-Level Results}

Loan-level results imply a cut of credit supply; however, effects could be mitigated if firms can obtain credit from the less affected banks. Hence, to assess this macro effect of dynamic provisioning, we turn to firm-level estimations. The first model is

$$
\begin{aligned}
& \Delta \log \text { Commitment }(2000: \mathrm{Q} 1-2001: \mathrm{Q})_{f} \\
& =\delta_{p}+\delta_{i}+\beta \text { Dynamic Provision (for 1998:Q4) } \\
& \quad+\operatorname{controls}_{f}+\varepsilon_{f},
\end{aligned}
$$

where $\Delta \log$ Commitment (2000:Q1-2001:Q2) $)_{f}$ is the change in the logarithm of (strictly positive) committed credit by all banks to firm $f, \delta_{p}$ and $\delta_{i}$ are the province and industry fixed effects, Dynamic Provision (for 1998:Q4) $)_{f}$ is the same dynamic provisioning variable as before for all banks that were lending to the firm $f$ prior to the introduction (weighting each bank value by its loan volume to firm $f$ prior to the shock over total bank

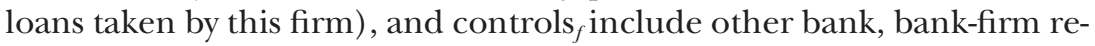
lationship, and firm characteristics for all banks of firm $f ; \varepsilon_{f}$ is the error term. Because the analysis is at the firm level, firm fixed effects cannot be included; however, we know from the loan-level regressions that the estimated coefficients are identical with and without controlling for firm fixed effects. Hence, controlling for firm variables is enough to control for all firm fundamentals.

The obtained credit after the shock can be from both "current" and "noncurrent" banks (that did not lend to the firm prior to the shock). Hence we analyze whether firms are able to absorb the impact of the shock 
(which was affecting the banks they were borrowing from prior to the shock) by obtaining more credit from current and/or noncurrent banks. The sample and basis periods are the same as for the loan-level analysis. The standard errors are clustered at the main bank level (and triple clustered at the first, second, and third main bank levels in robustness).

In models $12-16$ in table 2 we consecutively regress our main dependent credit variable at the firm level, that is, $\Delta \log$ Commitment (2000: Q1-2001:Q2), in addition to $\Delta \log$ Drawn (2000:Q1-2001:Q2), and firm $\Delta \log$ Total Assets (1999:Q4-2001:Q4), $\Delta \log$ Employees (1999:Q4-2001:

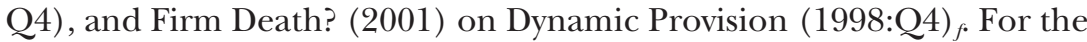
main credit variable, models 12 and 13, the estimated coefficients on Dynamic Provision are insignificant. The gray lines in figure 2 show that the coefficients on Dynamic Provision are never significant (though economically significant only in the first quarters but with $p$-values of 20 percent), thus suggesting that in good times firms can swiftly turn to different banks outside the set of current banks that were employed prior to the introduction or even sufficiently shift borrowing within this set of current banks to less affected ones. Granting of loan applications by new banks is relatively high in good times (fig. 4). Consistent with this view, we find no real effects on firm total assets, employment, or survival in models 14-16.

In sum, results show that dynamic provisioning in good times can reduce the supply of credit by the affected banks but that the impact on firm financing and performance seems low. Hence dynamic provisioning introduced at the right time can be a potent countercyclical tool that modifies banks' lending behavior but that is also fairly benign in its impact on firms. On the other hand, there are some unanticipated effects of the policy: Tighter capital requirements can induce risk taking by regulated banks and regulatory arbitrage by nonregulated banks (foreign branches), the latter undoing part of the policy as regulatory arbitrage usually does. However, the higher supply of credit by nonregulated banks and by regulated but less affected banks substantially mitigates the negative credit and real effects at the firm level (the 4 percentage point difference in loan-level credit, in the absence of an effect on firm-level credit, means that the difference does not arise entirely because banks with higher provisioning cut lending by the full 4 percentage points).

\section{In Bad Times: Dynamic Provision Funds and Crisis, Floor Lowering, and New Requirements}

\section{A. The Specifics of the Crisis Shock and the Floor Lowering}

We now turn to the analysis in bad times when the countercyclical nature of dynamic provisioning was operational by the unexpected crisis shock (as the dynamic provision flow turns negative and the stock starts to de- 


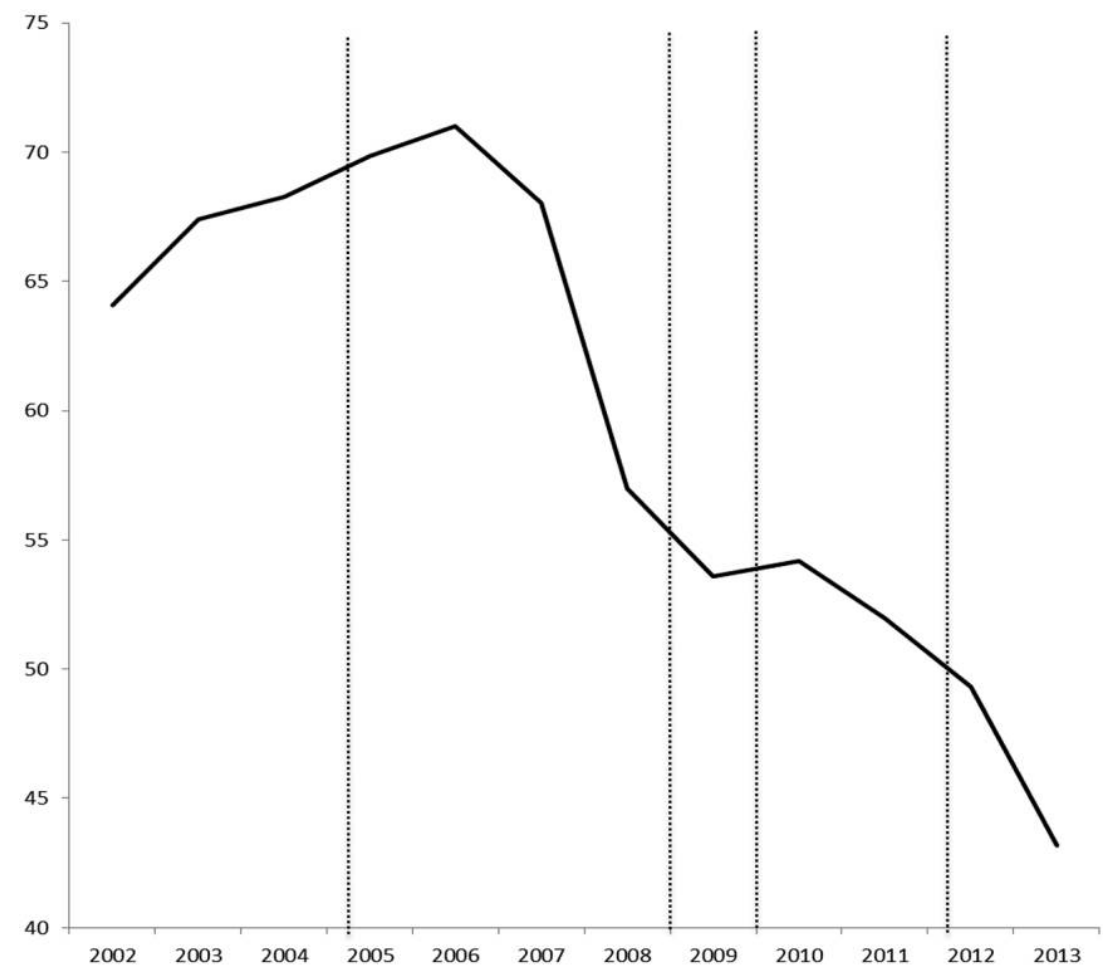

FIG. 4.- The probability that one or more loan applications are granted by a noncurrent ("new") bank. The solid line represents the probability that one or more loan applications by a firm to a noncurrent ("new") bank are granted. The dashed vertical lines represent the timing of the policy shocks.

cline) and two further policy shocks decreased the provisioning floor. For the crisis shock we calculate how much each bank had built up as dynamic provision funds (over assets) just prior to the onset of the crisis in Spain. The variable Dynamic Provision Funds (2007:Q4) varies across banks, with a mean of 1.17 and a standard deviation that equals 0.23 (see table 5 for summary statistics). The lowering in 2008:Q4 of the floor of provision funds from 33 percent to 10 percent and in 2009:Q4 to 0 percent affected mostly the banks that had not reached the maximum in their dynamic provision funds before. ${ }^{12}$ It is captured by the dummy variable $d$ (Dynamic Provision Funds $<1.25$ ), which equals one if the dynamic provision funds

${ }^{12}$ Banks for which the formula states that their provision funds should be higher than the ceiling can have provision funds at the ceiling, but because of the higher formula value, they cannot immediately release funds since their theoretical value is even higher than the ceiling. Therefore, these banks are less affected immediately after the floor was reduced or eliminated. 


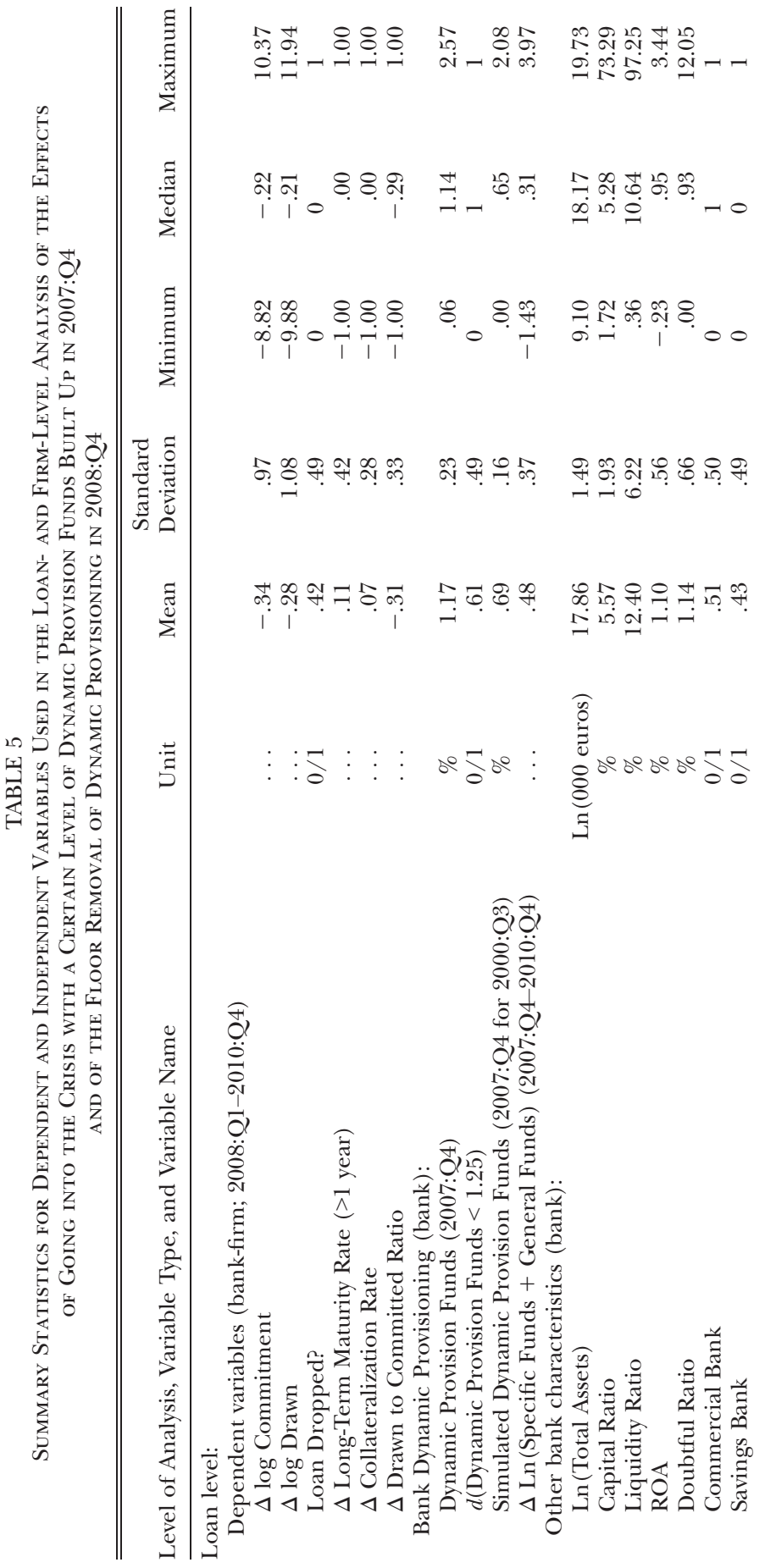

2154

This content downloaded from 084.089.157.043 on April 09, 2019 09:14:29 AM 


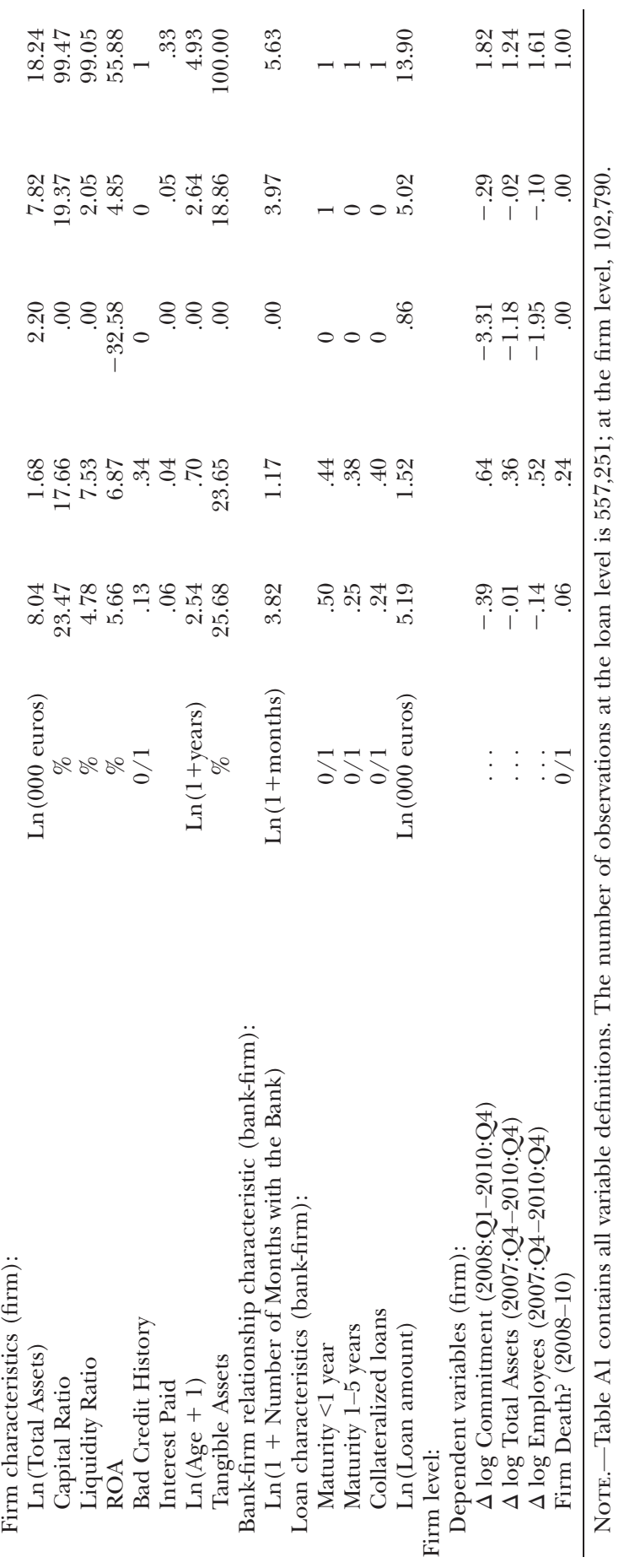

2155

This content downloaded from 084.089.157.043 on April 09, 2019 09:14:29 AM 


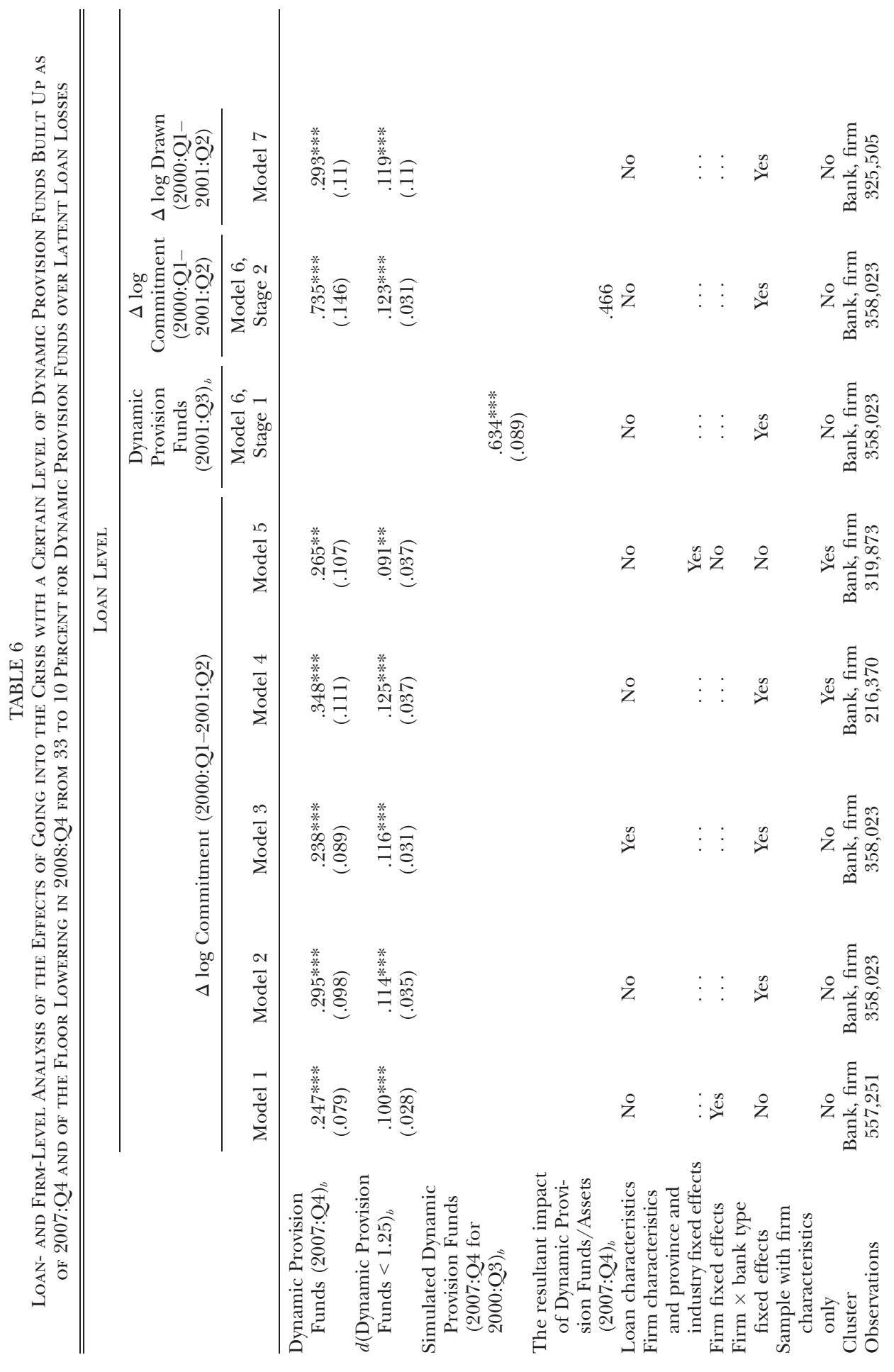

2156

This content downloaded from 084.089.157.043 on April 09, 2019 09:14:29 AM

All use subject to University of Chicago Press Terms and Conditions (http://www.journals.uchicago.edu/t-and-c). 


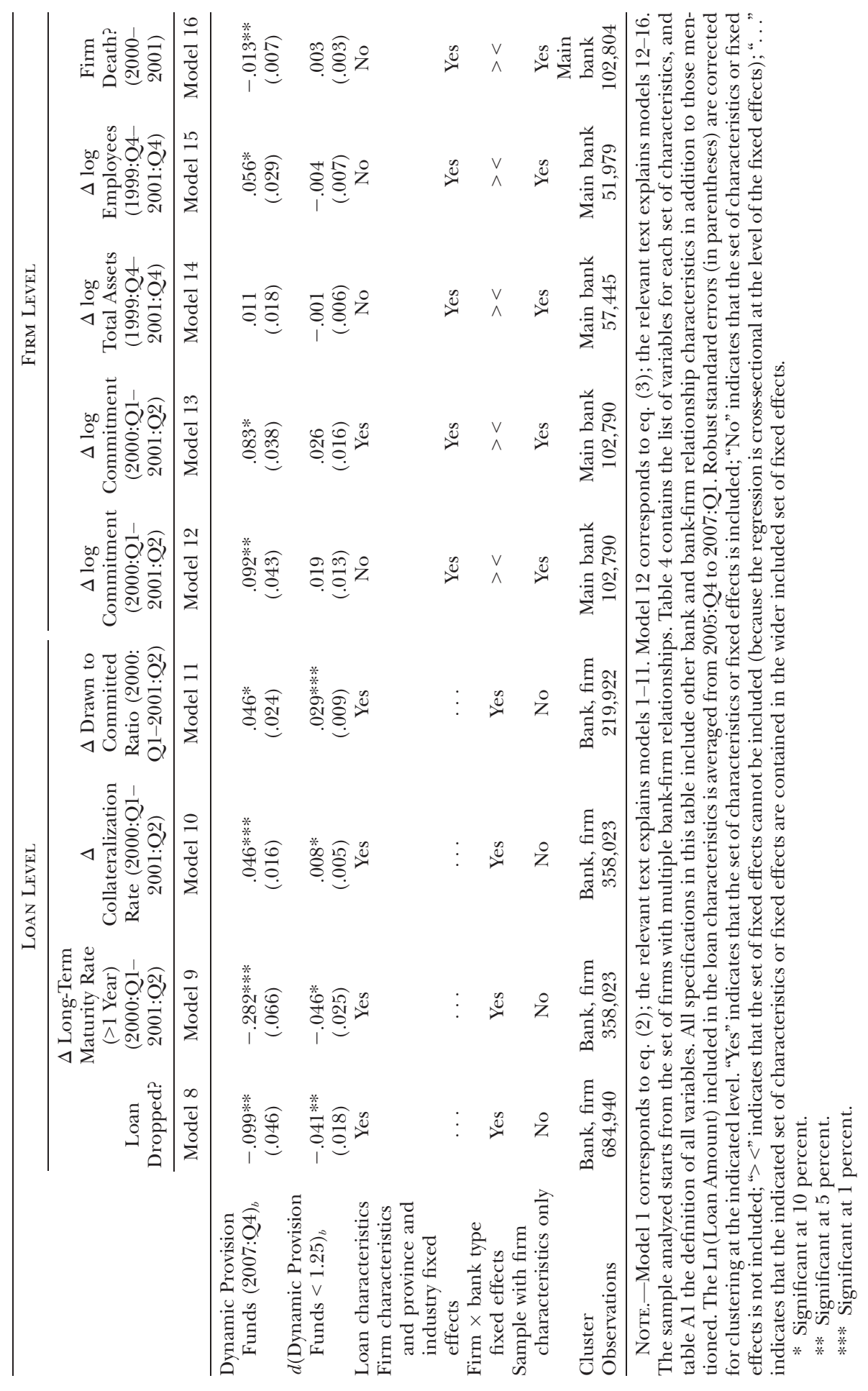

2157 
are below the ceiling of 125 percent of latent loan losses just before the policy shock and equals zero otherwise, with a mean value of 0.61 . For the quarter-on-quarter time-varying results, this variable is calculated in each quarter.

\section{B. Loan-Level Results}

The variables Dynamic Provision Funds and $d$ (Dynamic Provision Funds $<$ 1.25) replace Dynamic Provision in equation (2), but otherwise the estimated models in table 6 run in parallel with those in table 2. For example, in models $1-5$ we regress $\Delta \log$ Commitment from 2008:Q1 to 2010:Q4 on the two dynamic provisioning variables and the indicated sets of controls. Both coefficients are positive and statistically and economically significant. Take again model 4 saturated with firm $\times$ bank type fixed effects. The estimated coefficient on Dynamic Provision Funds equals $0.348^{\text {**** }}$, which implies that one standard deviation more in terms of funds (i.e., 0.23) delivers 8 percentage points more credit growth between 2008:Q1 and 2010:Q4 and that at a bank with a mean level of funds (i.e., 1.17 percent), lending grew by almost 41 percentage points more than at a bank with zero funds. The estimated coefficient on $d$ (Dynamic Provision Funds $<1.25$ ) equals $0.125^{* * * *}$, implying that lending at banks below their ceiling grew by 13 percentage points more.

Figure 5 again crucially displays the estimated coefficients (and confidence intervals) for model 4 for each quarter from 2008:Q1 to 2010:Q4. The graphs show that the estimates for Dynamic Provision Funds are permanently positive during the crisis, are statistically significant over all horizons after the start of the crisis, and have higher values in 2010 than in the beginning of the crisis. Figure 6 shows the impact of two floor reductions on credit commitment. The highest positive effects are for the two quarters when the policy shocks take place (and for the first shock, effects are also statistically significant in the preceding quarter when the reduction was announced and in the quarter after). ${ }^{13}$ Note that at the beginning of the crisis, the second main variable has a relatively stronger effect than the first one, also as compared to the 2010 period.

Returning to table 6 , results are similar when we perform the robustness tests as in table 2 or putting one variable alone (not reported) and when instrumenting (in model 6) the actual Dynamic Provision Funds in 2007:

\footnotetext{
${ }^{13}$ Only banks with DPF below 125 percent were allowed to immediately release funds. In a regression discontinuity setup we find that floor reductions in 2008:Q3/4 and 2009:Q4 spur banks below 125 percent to increase the supply of credit more than banks above in the theoretical value of the formula (estimates available on request). Results are also similar if we use alternative measures, e.g., dummies for the lower 25 or 50 percent in DPF. Almost all banks maintain positive buffers possibly to avoid a binding regulatory limit (e.g., Flannery and Rangan 2008).
} 


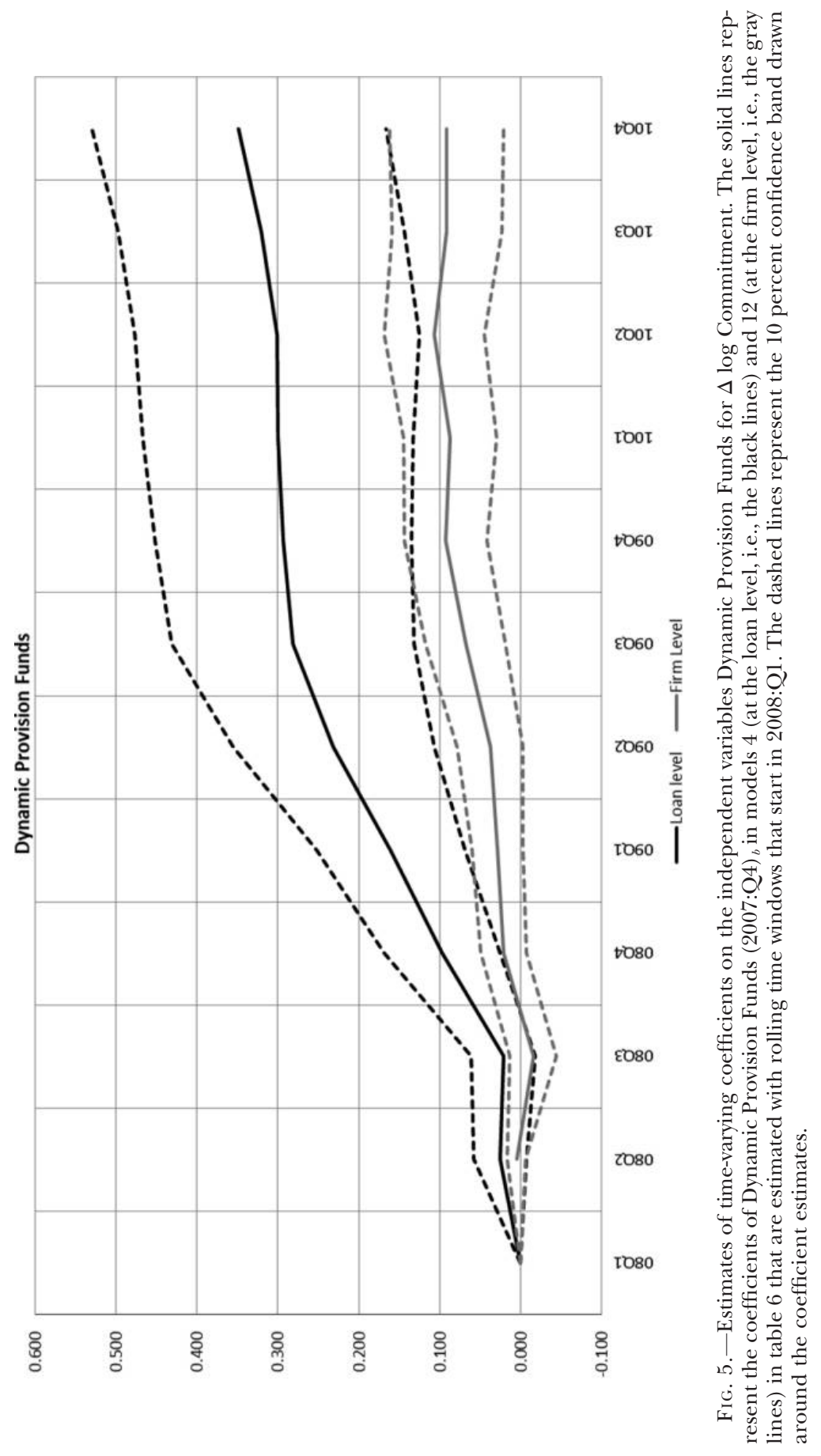

This content downloaded from 084.089.157.043 on April 09, 2019 09:14:29 AM 


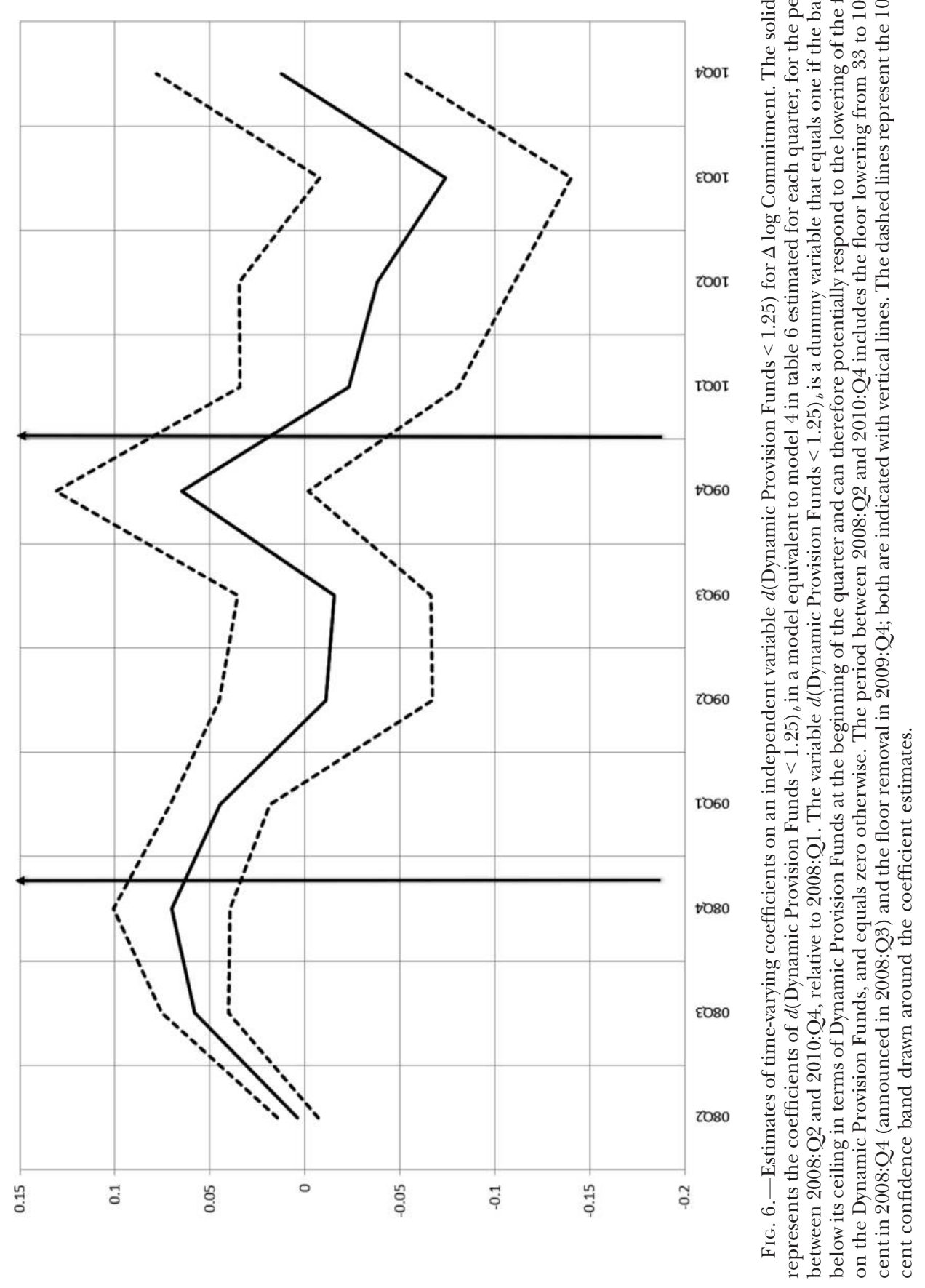

This content downloaded from 084.089.157.043 on April 09, 2019 09:14:29 AM

All use subject to University of Chicago Press Terms and Conditions (http://www.journals.uchicago.edu/t-and-c). 
Q4 with the simulated funds fixing the bank loan portfolio in 2000:Q3! By instrumenting with the part explained by the regulation (the formula) applied to the portfolio 7 years earlier (i.e., the moment of introduction of dynamic provisions), we remove the potentially endogenous part (banks could have dynamically provisioned more than required by regulation) in 2007:Q4. The estimated coefficient in the first stage equals $0.634^{* * * *}$, and the instrument does not suffer from a weak instrument problem. The pass-through effect of Dynamic Provision Funds in 2007:Q4 now equals $0.466(=0.634 \times 0.735)$. We also again turn to the two-stage model that allows the effect of changes in dynamic provisioning in lending to go through the changes in the specific and general funds. The estimates are in model 2 in the previously introduced table 3. Controlling for bank risk measures, the changes in Dynamic Provision Funds/Assets (2007:Q4) now have an estimated coefficient equal to $-0.866^{* * *}$. The changes in those funds then result in committed lending with an estimated coefficient that equals $-0.335^{* *}$, for an overall impact of dynamic provision funds that equals 0.290 ( $=-0.866 \times-0.335)$. Therefore, countercyclical capital buffers work positively on credit supply via saving on capital in crisis times (when bank profits and shareholder funds' access are scarce).

Results are very similar for drawn credit (model 7 ), drawn to committed (model 11), and the extensive margin of loan continuation (model 8). But interestingly, these same banks also shorten loan maturity (model 9) and increase collateral requirements (model 10) in both a statistically significant and economically relevant manner, possibly to compensate for the higher risk they take by lending more during the crisis.

In table 7 we turn to the effects across bank and firm characteristics. The impact of the provisioning on credit supply was absorbed best by well-capitalized banks with a low NPL ratio. Hence, highly leveraged banks with high NPL ratios may face a capital requirement in the market that is higher and hence more binding than the regulatory requirement. A loosening of the regulatory requirement may therefore have a more muted effect on credit supply for those riskier banks. The floor lowering also led banks below the ceiling to grant more credit supply to firms with less equity or longer time with the bank, consistent with risk shifting (gambling for resurrection and zombie lending). Hence, both credit (including risk shifting) and real effects are not the same when the regulator increases requirements in good times to have higher buffers in bad times than when the regulator just lowers requirements in bad times.

\section{Firm-Level Results}

The firm-level estimates in models 12-16 in table 6 (and fig. 5) suggest that firms cannot substitute for the impact of dynamic provisioning we document at the loan level. In model 12, for example, the estimated 
TABLE 7

Analysis of the Changes in Committed Lending of Going into the Crisis with a Certain level of Dynamic Provision Funds Built Up in 2007:Q4 and of the Floor Lowering in 2008:Q4 from 33 to 10 Percent for Dynamic Provision Funds over Latent Loan Losses across Banks and Firms

\begin{tabular}{|c|c|c|}
\hline & Model 1 & Model 2 \\
\hline Dynamic Provision Funds (2007:Q4) ${ }_{b}\left(=\mathrm{DPF}_{b}\right)$ & $\begin{array}{l}.422 * * * \\
(.106)\end{array}$ & \\
\hline $\mathrm{DPF}_{b} \times \operatorname{Ln}(\text { Total Assets })_{b}$ & $\begin{array}{l}.031 \\
(.037)\end{array}$ & \\
\hline $\mathrm{DPF}_{b} \times$ Capital Ratio ${ }_{b}$ & $\begin{array}{l}.068^{* *} \\
(.03)\end{array}$ & \\
\hline $\mathrm{DPF}_{b} \times \mathrm{ROA}_{b}$ & $\begin{array}{c}-.199 \\
(.173)\end{array}$ & \\
\hline $\mathrm{DPF}_{b} \times \mathrm{NPL}_{b}$ & $\begin{array}{l}-.218 * * * \\
(.057)\end{array}$ & \\
\hline $\mathrm{DPF}_{b} \times \operatorname{Ln}(\text { Total Assets })_{f}$ & $\begin{array}{l}.009 \\
(.019)\end{array}$ & $\begin{array}{l}.010 \\
(.021)\end{array}$ \\
\hline $\mathrm{DPF}_{b} \times$ Capital Ratio $_{f}$ & $\begin{array}{l}.000 \\
(.001)\end{array}$ & $\begin{array}{l}.000 \\
(.001)\end{array}$ \\
\hline $\mathrm{DPF}_{b} \times \mathrm{ROA}_{f}$ & $\begin{array}{l}.001 \\
(.002)\end{array}$ & $\begin{array}{l}.001 \\
(.002)\end{array}$ \\
\hline $\mathrm{DPF}_{b} \times$ Bad Credit History $_{f}$ & $\begin{array}{r}-.033 \\
(.043)\end{array}$ & $\begin{array}{c}-.023 \\
(.042)\end{array}$ \\
\hline $\mathrm{DPF}_{b} \times$ Interest Paid $_{f}$ & $\begin{array}{l}.000 \\
(.388)\end{array}$ & $\begin{array}{c}-.274 \\
(.386)\end{array}$ \\
\hline $\mathrm{DFP}_{b} \times \operatorname{Ln}(1+\text { Number of Months with the Bank })_{b f}$ & $\begin{array}{l}.025 \\
(.019)\end{array}$ & $\begin{array}{l}.017 \\
(.016)\end{array}$ \\
\hline$d(\text { Dynamic Provision Funds }<1.25)_{b}\left(=\mathrm{DP}_{b}\right)$ & $\begin{array}{l}.090 * * * \\
(.029)\end{array}$ & \\
\hline $\mathrm{DP}_{b} \times \operatorname{Ln}(\text { Total Assets })_{b}$ & $\begin{array}{r}-.015 \\
(.015)\end{array}$ & \\
\hline $\mathrm{DP}_{b} \times$ Capital Ratio $_{b}$ & $\begin{array}{r}-.026 \\
(.021)\end{array}$ & \\
\hline $\mathrm{DP}_{b} \times \mathrm{ROA}_{b}$ & $\begin{aligned}-.008 \\
(.082)\end{aligned}$ & \\
\hline $\mathrm{DP}_{b} \times \mathrm{NPL}_{b}$ & $\begin{array}{l}-.116^{* * * *} \\
(.041)\end{array}$ & \\
\hline $\mathrm{DP}_{b} \times \operatorname{Ln}(\text { Total Assets })_{f}$ & $\begin{array}{c}-.002 \\
(.008)\end{array}$ & $\begin{array}{l}.001 \\
(.008)\end{array}$ \\
\hline $\mathrm{DP}_{b} \times$ Capital Ratio $f$ & $\begin{array}{l}-.002 * * * \\
(.001)\end{array}$ & $\begin{array}{l}-.002 * * * \\
(.001)\end{array}$ \\
\hline $\mathrm{DP}_{b} \times \mathrm{ROA}_{f}$ & $\begin{array}{c}-.001 \\
(.001)\end{array}$ & $\begin{array}{c}-.001 \\
(.001)\end{array}$ \\
\hline $\mathrm{DP}_{b} \times$ Bad Credit History $_{f}$ & $\begin{array}{c}-.003 \\
(.02)\end{array}$ & $\begin{array}{c}-.003 \\
(.019)\end{array}$ \\
\hline $\mathrm{DP}_{b} \times$ Interest Paid $_{f}$ & $\begin{array}{c}-.249 \\
(.218)\end{array}$ & $\begin{array}{r}-.337 * \\
(.204)\end{array}$ \\
\hline $\mathrm{DP}_{b} \times \operatorname{Ln}(1+\text { Number of Months with the Bank })_{b f}$ & $\begin{array}{l}.015^{* *} \\
(.007)\end{array}$ & $\begin{array}{l}.013^{*} \\
(.007)\end{array}$ \\
\hline Firm $\times$ bank type fixed effects & Yes & Yes \\
\hline Bank fixed effects & No & Yes \\
\hline Cluster & Bank, firm & Bank, firm \\
\hline Observations & 208,137 & 208,137 \\
\hline
\end{tabular}

Note.-The dependent variable is $\Delta \log$ Commitment (2008:Q1-2010:Q4). The sample analyzed is the set of firms with multiple bank-firm relationships and firm characteristics. Table Al contains all variable definitions. All specifications in this table include other bank and bank-firm relationship characteristics in addition to those mentioned. Robust standard errors (in parentheses) are corrected for clustering at the indicated level. "Yes" indicates that the set of characteristics or fixed effects is included.

* Significant at 10 percent.

** Significant at 5 percent.

*** Significant at 1 percent. 
coefficient on Dynamic Provision Funds equals $0.092^{* *}$, implying that firms dealing with banks holding 1 percentage point more in precrisis funds receive 9 percentage points more in committed credit than when dealing with other banks, partly offsetting the contraction in committed borrowing by 34 percent for the mean firm. Figure 5 (the gray lines) shows that this effect is permanent, statistically significant, and large, though the effect stabilizes over 2010 (probably because funds start depleting; see Sec. IV.D below). All in all, given that we control for bank and firm characteristics and, in the loan-level regressions, the coefficients in the models with firm fixed effects and the models with firm variables are not statistically different, the firm-level results can be interpreted as being driven by credit supply.

There are important real effects associated. Employment growth at firms borrowing from banks with higher precrisis buffers relatively increases during the crisis period. The estimated coefficient of $0.056^{*}$ (model 15) implies a 6 percentage point higher growth for each 1 percentage point more in funds (mean growth was -14 percent). Firm survival is similarly affected. The estimate of $-0.013^{* *}$ in model 16 implies that a 1 percentage point higher precrisis buffer results in a 1 percentage point higher likelihood of survival. As figure 4 shows for the granting of loan applications, substitution of banks is more difficult in bad times than in good times. The estimated coefficients on the floor variables (fig. 6), though statistically significant around the quarters related to the floor reductions, turn statistically insignificant over the entire impact period. Consistent with these results, we find no real effects associated to the floor reductions over the whole 2008-10 period.

\section{Increase in General Provisions in 2012}

The last shock we analyze is a change in the law in 2012:Q1 and Q2 that increased the provisions that banks needed to make on all their (performing and nonperforming) lending exposure to construction and real estate firms as of 2011:Q4. ${ }^{14}$ The increase in provisions could be accomplished until the end of 2012, and figure 1 shows this large increase of around $\$ 85$ billion in provisioning, which is around 8.5 percent of annual GDP (and compared to $\$ 20$ billion 1 year before). We investigate the impact of the preshock bank-level exposure to construction and real estate firms on its lending to nonconstruction or real estate-related firms.

${ }^{14}$ In February 2012 banks had to provision 7 percent for all performing loans related to construction and the real estate sector in their portfolio. In May 2012 these provisions were increased by law depending on the nature of the assets: an additional 45 percent for land, 7 percent for real estate developments completed, and 22 percent for real estate developments in progress. Hence these provisions constituted a one-time ad hoc increase. The law also tightened provisioning for nonperforming construction and real estate loans. All these provisions were charged by the banks as specific provisions by 2012:Q4. 


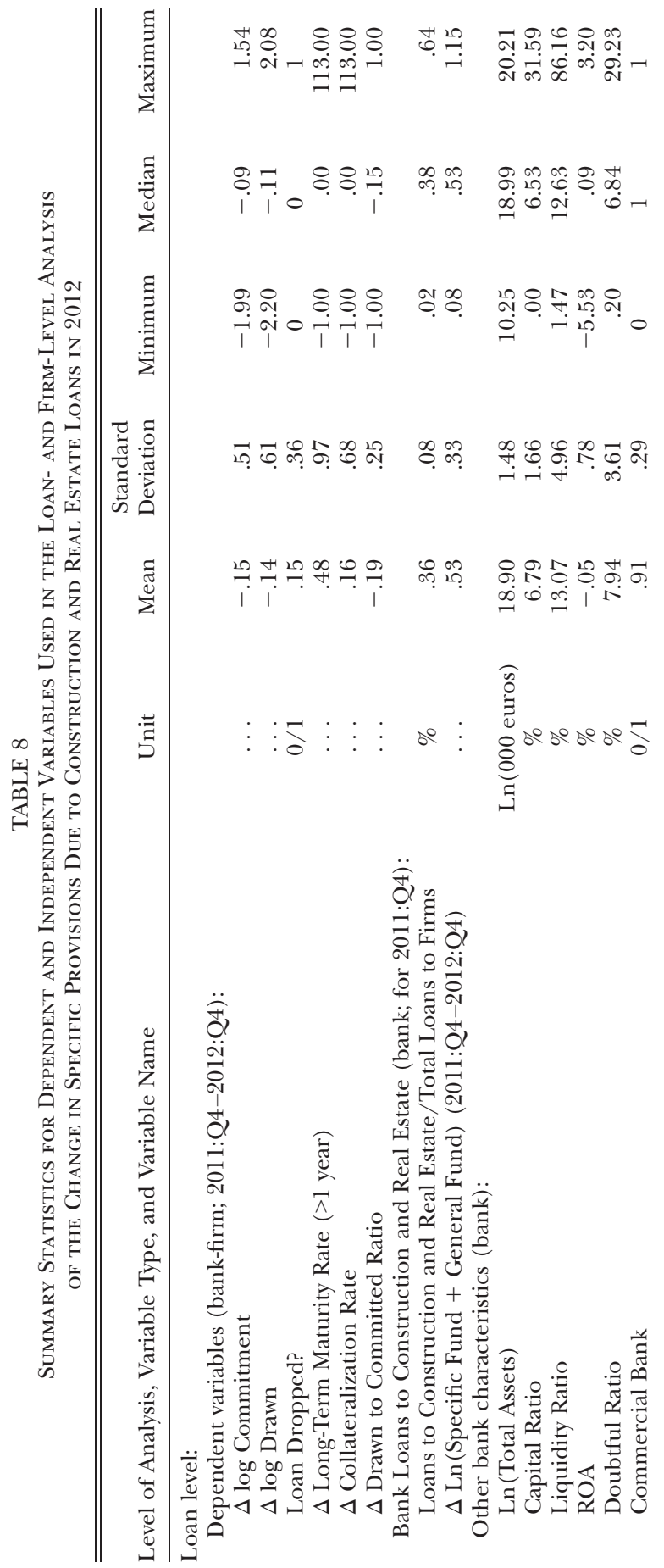

2164

This content downloaded from 084.089.157.043 on April 09, 2019 09:14:29 AM 


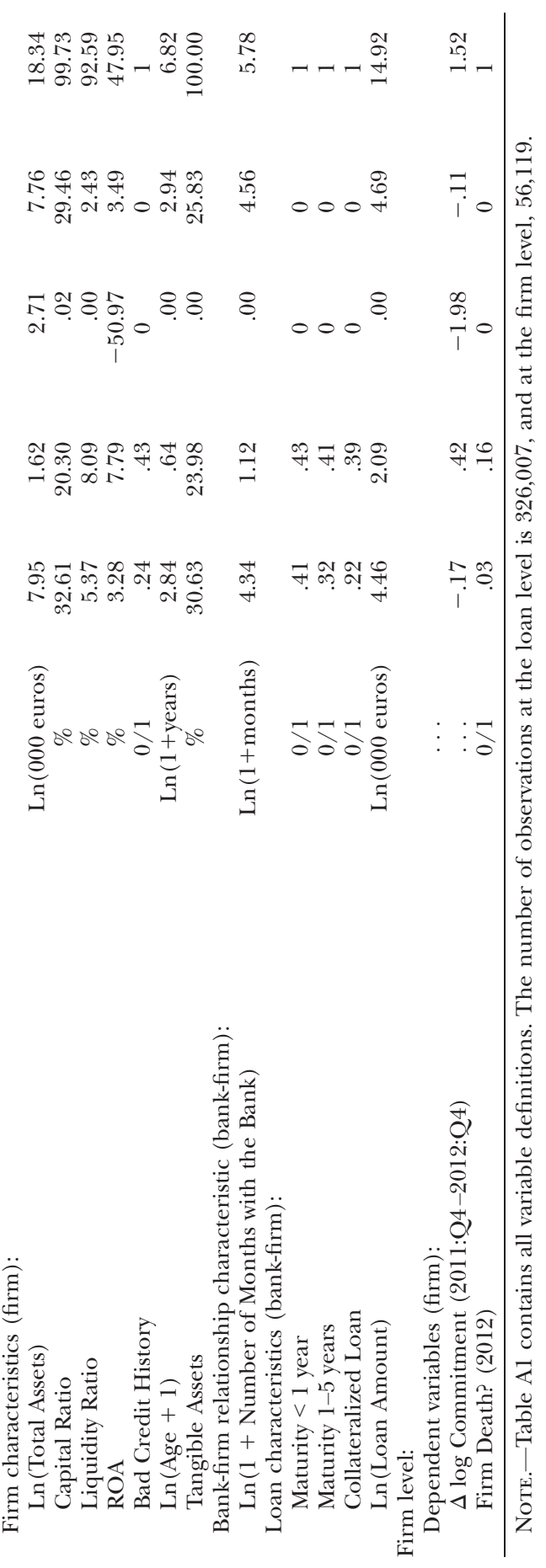

2165

This content downloaded from 084.089.157.043 on April 09, 2019 09:14:29 AM 


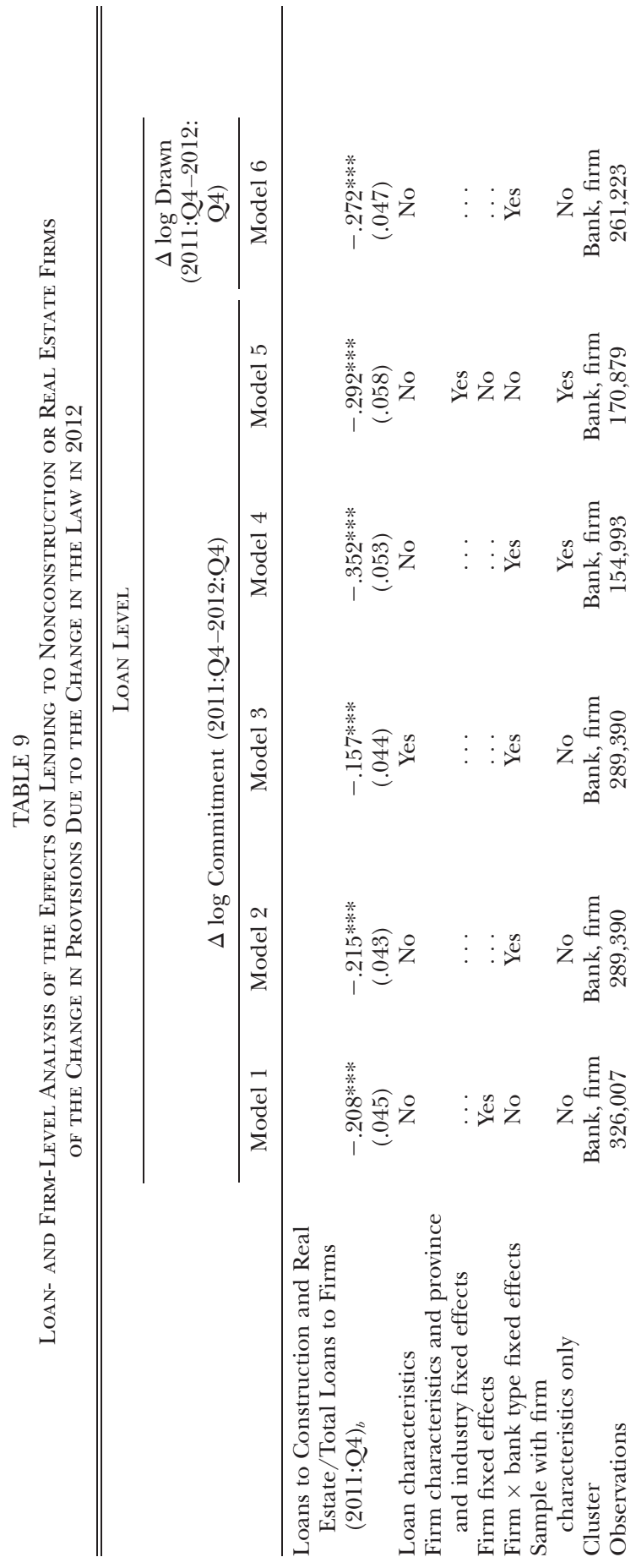

2166

This content downloaded from 084.089.157.043 on April 09, 2019 09:14:29 AM 


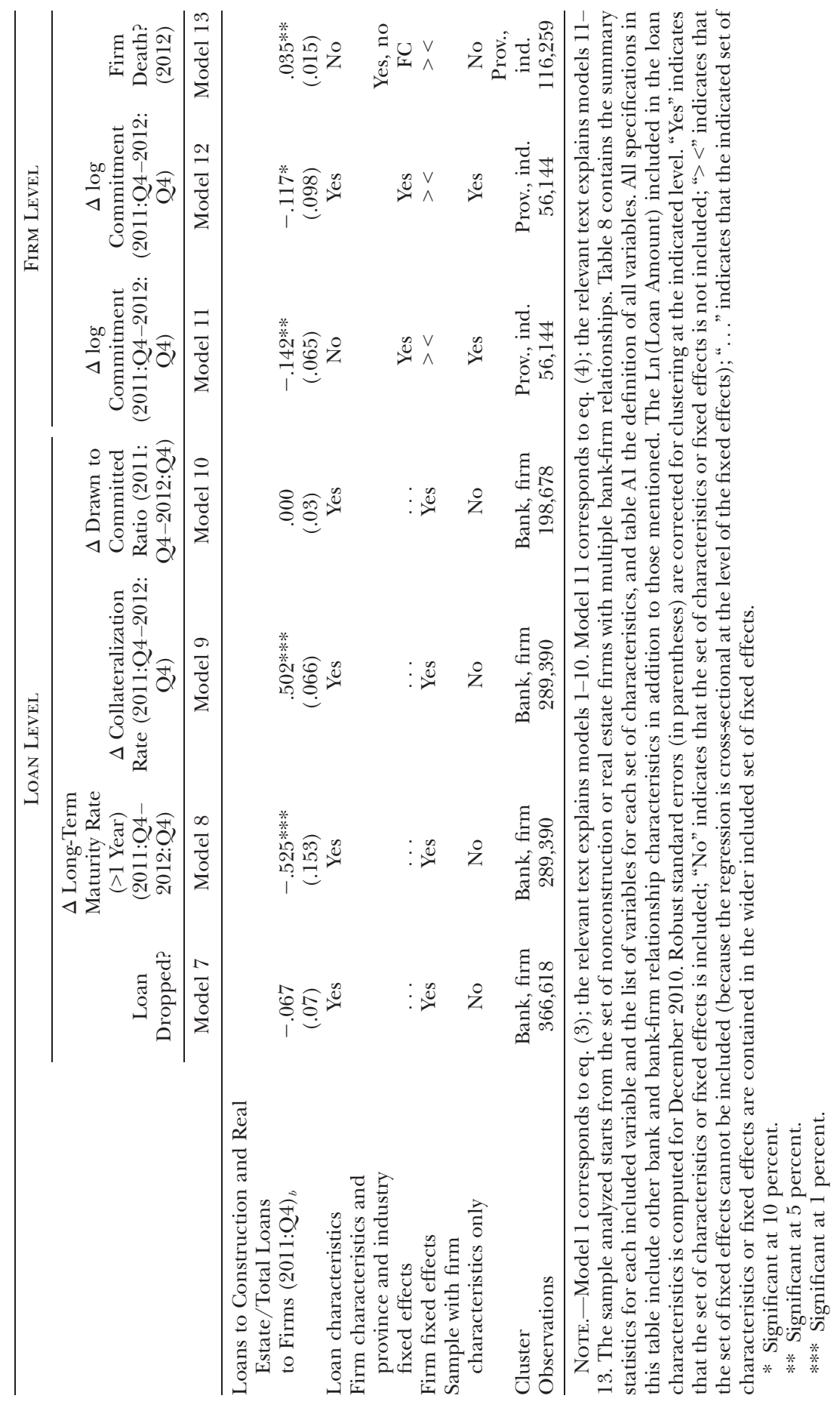

2167

This content downloaded from 084.089.157.043 on April 09, 2019 09:14:29 AM All use subject to University of Chicago Press Terms and Conditions (http://www.journals.uchicago.edu/t-and-c). 
Construction and Real Estate/Total Loans to Firms (2011:Q4) replaces Dynamic Provision in equation (2), but otherwise table 9 lines up with table 2 (see table 8 for the summary statistics).

In models $1-5$ of table 9 we regress $\Delta \log$ Commitment from 2011:Q4 to 2012:Q4 on the construction and real estate exposure variable and the indicated sets of characteristics and fixed effects. The estimated coefficients in all cases are negative, statistically significant, and economically relevant. In model 4 , for example, the estimated coefficient on this variable equals $-0.352^{* * *}$, which implies that one standard deviation more exposure (i.e., 0.08) results in 3 percentage points less growth in lending to nonconstruction or real estate firms between 2011:Q4 and 2012:Q4, a sizable effect given that committed lending to these firms contracted on average by 15 percent. Crucially, this effect is again permanent (over 2012 and 2013) as figure 7 demonstrates, and it can be traced through the increase in the overall provisioning as model 3 in table 3 shows. Moreover, the increase in provisioning imposed on banks leads to a statistically significant contraction in credit drawn, shortening in maturity, and tightening of collateralization requirements (models 6, 8, and 9, table 9). Also, given that real estate assets are affected in the crisis, it is important to note that all the results are significant only after (and not before) the policy change, as figure 7 shows.

Importantly, at the firm level committed credit falls (models 11 and 12 and fig. 7), while firm death increases (no balance sheet data are yet available). For firms dealing with banks that are average in terms of their lending to construction and real estate firms (i.e., equal to 0.36), the tightening in requirements means a contraction in committed credit at the firm level by at least 4 percentage points and a 1 percentage point lower likelihood of survival. These estimates vividly demonstrate the costs associated with a required increase in capital in crisis times. Again analyzing the granting of loan applications shows the difficulty of substituting banks in crisis times (fig. 4).

Finally, compositional changes in credit supply are again interesting (table 10). Banks with higher requirements expand relatively more supply of credit to firms with lower profits, with a bad credit history, and (marginally significant) with a longer relationship, though these banks also expand to firms with lower yield (though it could be consistent with risk shifting as zombie lending can imply a lower interest rate, so that the firm reduces the risk of default). Moreover, contractive effects are overall weaker for lowly capitalized banks with a high ratio of NPLs. These results are consistent with risk shifting (including zombie lending).

\section{Conclusions}

We study the effects of dynamic provisioning (procyclical capital requirements generating countercyclical bank capital buffers) on the supply of 


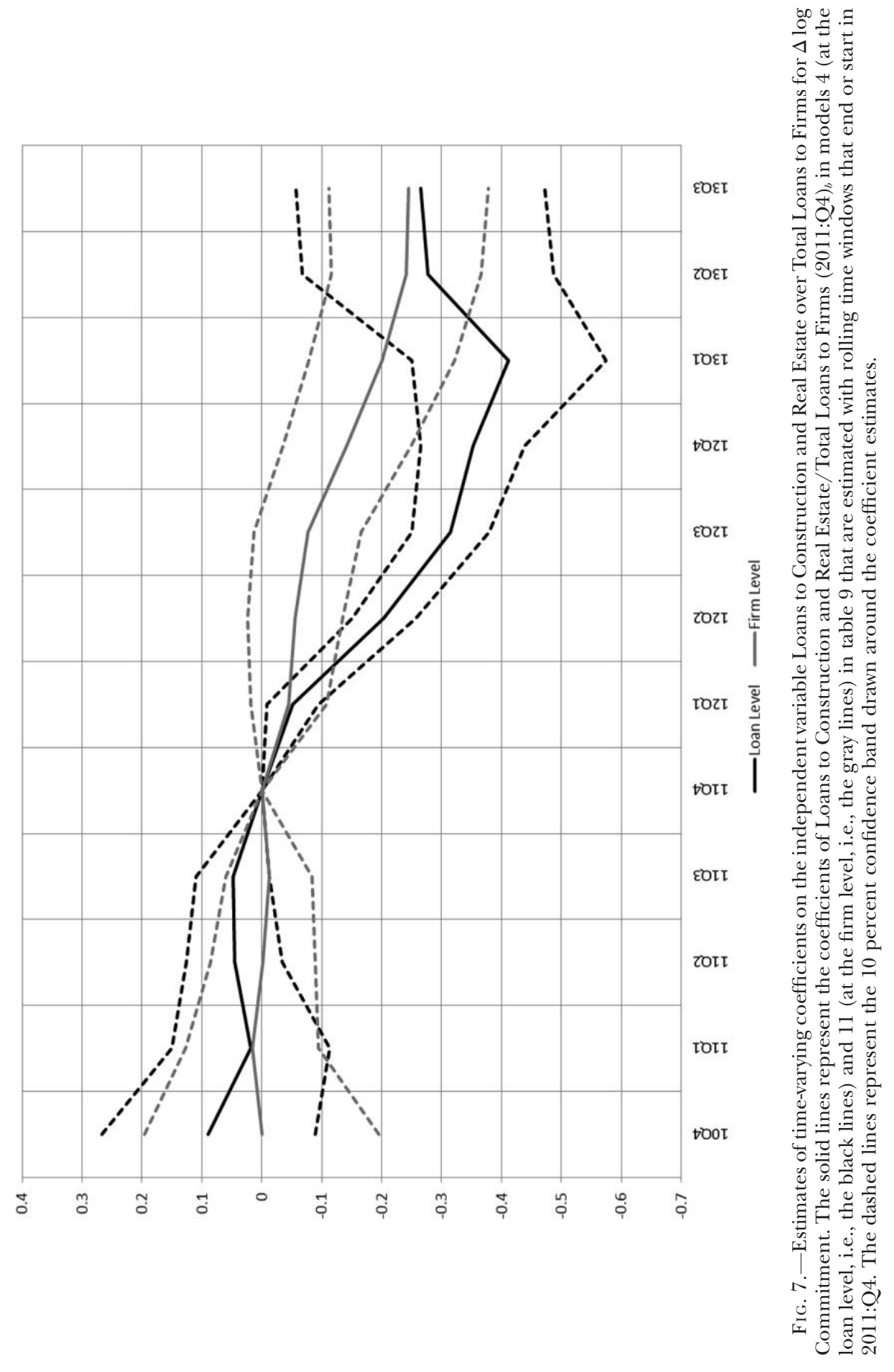

This content downloaded from 084.089.157.043 on April 09, 2019 09:14:29 AM

All use subject to University of Chicago Press Terms and Conditions (http://www.journals.uchicago.edu/t-and-c). 
credit to firms and their real performance in good and bad times. Spain in the period between 1999 and 2013 offers an excellent setting to empirically identify these effects, given the many policy experiments with dynamic provisioning (generating time-variant bank-specific shocks), the full credit cycle with an unexpected crisis shock to test the countercyclical nature of the policy, and the unique microdata that are available.

Our results overall show that dynamic provisioning mitigates credit supply cycles, with strong positive aggregate firm-level credit, employment, and survival effects in crisis times, when switching from banks with low

TABLE 10

Analysis of the Changes in Committed Lending to Nonconstruction or Real Estate Firms of the Change in Provisions Due to the Change in the Law in 2012 across Banks and Firms

\begin{tabular}{|c|c|c|}
\hline Model & Model 1 & Model 2 \\
\hline \multicolumn{3}{|l|}{ Loans to Construction and Real Estate/Total } \\
\hline Loans to Firms $(2011: Q 4)_{b}\left(=\mathrm{CRE}_{b}\right)$ & $\begin{array}{l}-.210 * * \\
(.092)\end{array}$ & \\
\hline $\mathrm{CRE}_{b} \times \operatorname{Ln}(\text { Total Assets })_{b}$ & $\begin{array}{r}-.028 \\
(.046)\end{array}$ & \\
\hline $\mathrm{CRE}_{b} \times$ Capital Ratio $_{b}$ & $\begin{array}{l}-.059 * * * \\
(.022)\end{array}$ & \\
\hline $\mathrm{CRE}_{b} \times \mathrm{ROA}_{b}$ & $\begin{array}{l}-.153 \\
(.157)\end{array}$ & \\
\hline $\mathrm{CRE}_{b} \times$ Doubtful Ratio $_{b}$ & $\begin{array}{l}.029 * * \\
(.013)\end{array}$ & \\
\hline $\mathrm{CRE}_{b} \times \operatorname{Ln}(\text { Total Assets })_{f}$ & $\begin{aligned}-.013 \\
(.024)\end{aligned}$ & $\begin{array}{l}-.019 \\
(.025)\end{array}$ \\
\hline $\mathrm{CRE}_{b} \times$ Capital Ratio $_{f}$ & $\begin{array}{l}.001 \\
(.002)\end{array}$ & $\begin{array}{l}.001 \\
(.002)\end{array}$ \\
\hline $\mathrm{CRE}_{b} \times \mathrm{ROA}_{f}$ & $\begin{array}{l}-.015^{* * * *} \\
(.005)\end{array}$ & $\begin{array}{l}-.015 * * * \\
(.005)\end{array}$ \\
\hline $\mathrm{CRE}_{b} \times$ Bad Credit History $_{f}$ & $\begin{array}{l}.236^{* * * *} \\
(.078)\end{array}$ & $\begin{array}{l}.230 * * * \\
(.077)\end{array}$ \\
\hline $\mathrm{CRE}_{b} \times$ Interest Paid $_{f}$ & $\begin{array}{r}-1.262^{*} \\
(.715)\end{array}$ & $\begin{aligned}-1.247^{*} \\
(.721)\end{aligned}$ \\
\hline $\mathrm{CRE}_{b} \times \operatorname{Ln}(1+\text { Number of Months with the Bank })_{b f}$ & $\begin{array}{l}.032 \\
(.034)\end{array}$ & $\begin{array}{l}.044 \\
(.031)\end{array}$ \\
\hline Firm $\times$ bank type fixed effects & Yes & Yes \\
\hline Bank fixed effects & No & Yes \\
\hline Cluster & Bank, firm & Bank, firm \\
\hline Observations & 74,364 & 74,364 \\
\hline
\end{tabular}

Note.-The dependent variable is $\Delta \log$ Commitment (2011:Q4-2012:Q4). The sample analyzed is the set of firms with multiple bank-firm relationships and firm characteristics. Table Al contains all variable definitions. All specifications in this table include other bank and bank-firm relationship characteristics in addition to those mentioned. Robust standard errors (in parentheses) are corrected for clustering at the indicated level. "Yes" indicates that the set of characteristics or fixed effects is included.

* Significant at 10 percent.

** Significant at 5 percent.

*** Significant at 1 percent. 
to high capital buffers and to other sources of finance is difficult. Our results suggest that the mechanism works through saving capital, as in crisis times bank profits and new shareholder funds to raise new capital are scarce and costly. While the effect on credit supplied by a specific bank to a specific firm is always economically strong, in good times dynamic provisioning is substantially weaker in halting a credit boom at the firm level as firms switch to less affected banks, including banks outside the regulatory perimeter (i.e., regulatory arbitrage). Moreover, the results suggest that the introduction of dynamic provisioning also leads banks to increase risk and search for yield, an unintended consequence of the policy indeed. Yet despite these system weaknesses, the bank buffers build-up in good times clearly helped to mitigate the credit crunch in bad times, when switching banks turns problematic. With respect to upholding real activity and avoiding risk shifting, results suggest that it is better to increase capital buffers in good times than change requirements for lowly capitalized banks in crisis times. Though the low dynamic provision funds (equaled only around 1.25 percent of total loans) are good for empirical identification, ultimately they were overwhelmed by the crisis. In fact, the one-off increase in provisions in 2012 contributed strongly to a credit crunch with substantial negative real effects.

Consequently, our findings hold important implications for macroprudential policy. Results indicate that bank procyclicality can be mitigated with countercyclical capital buffers, with less need for costly governmental bailouts and expansive monetary policy in crisis times. Basel III requires countercyclical bank capital buffers, and our findings support the reasoning that prevailed on these issues in Basel, the Group of 20, and some central banks: "Policymakers need to establish that countercyclical policy tools address cyclical vulnerabilities more effectively than simpler tools that are constant over the course of the cycle do" (Yellen 2011, 10).

Our results are also important for macroeconomic modeling as we show that in bad times (as compared also to good times) there are substantial real effects stemming from credit supply changes due to bank capital positions. Not only does aggregate bank capital matter, but as (we show) firms struggle to switch banks in bad times (because of, e.g., adverse selection; see, e.g., Dell'Ariccia and Marquez 2006), the distribution of bank capital per se drives macroeconomic real effects as well. Hence, bank (capital) heterogeneity matters for macroeconomics. Moreover, heterogeneity also matters across time, banks, firms, and loans. For example, banks differentially affected by policy change their composition of supply of credit, as in macroeconomic models with more than one lending opportunity (Matsuyama 2007). In addition, our results also suggest that not only policy constraints on capital matter but also market constraints (weaker effects in crisis times for banks with higher NPLs and leverage). 
Finally, our results inform the recent and contentious debate among academics, bankers, and policy makers on higher bank capital requirements and their impact on the supply of credit and the associated real effects for the overall economy (Hanson et al. 2011; Admati and Hellwig 2013). Witness in particular how overall effects were benign in good times, how the last policy experiment of tightening provisioning in the middle of the crisis was followed by a severe credit crunch with a matching real contraction, and how having plentiful precrisis capital buffers sustained credit and real activity in crisis times by obviating the need for raising capital precisely then when bank profits are low and access to shareholder funds is costly. In sum, our evidence suggests that bank capital should be raised in good times, not in bad times.

However, the supply of credit to more leveraged firms with higher yields can increase; hence higher bank capital may not always imply lower bank moral hazard (Gale 2010). On the other hand, there is behavior consistent with risk shifting when changing capital requirements in crisis times to banks with low capital. Therefore, on risk taking and regulatory arbitrage, both crucial for financial stability, our approach per se suggests that supervisors should collect exhaustive microdata and track - that is, supervise - in real time potential deviations from policy intentions. 


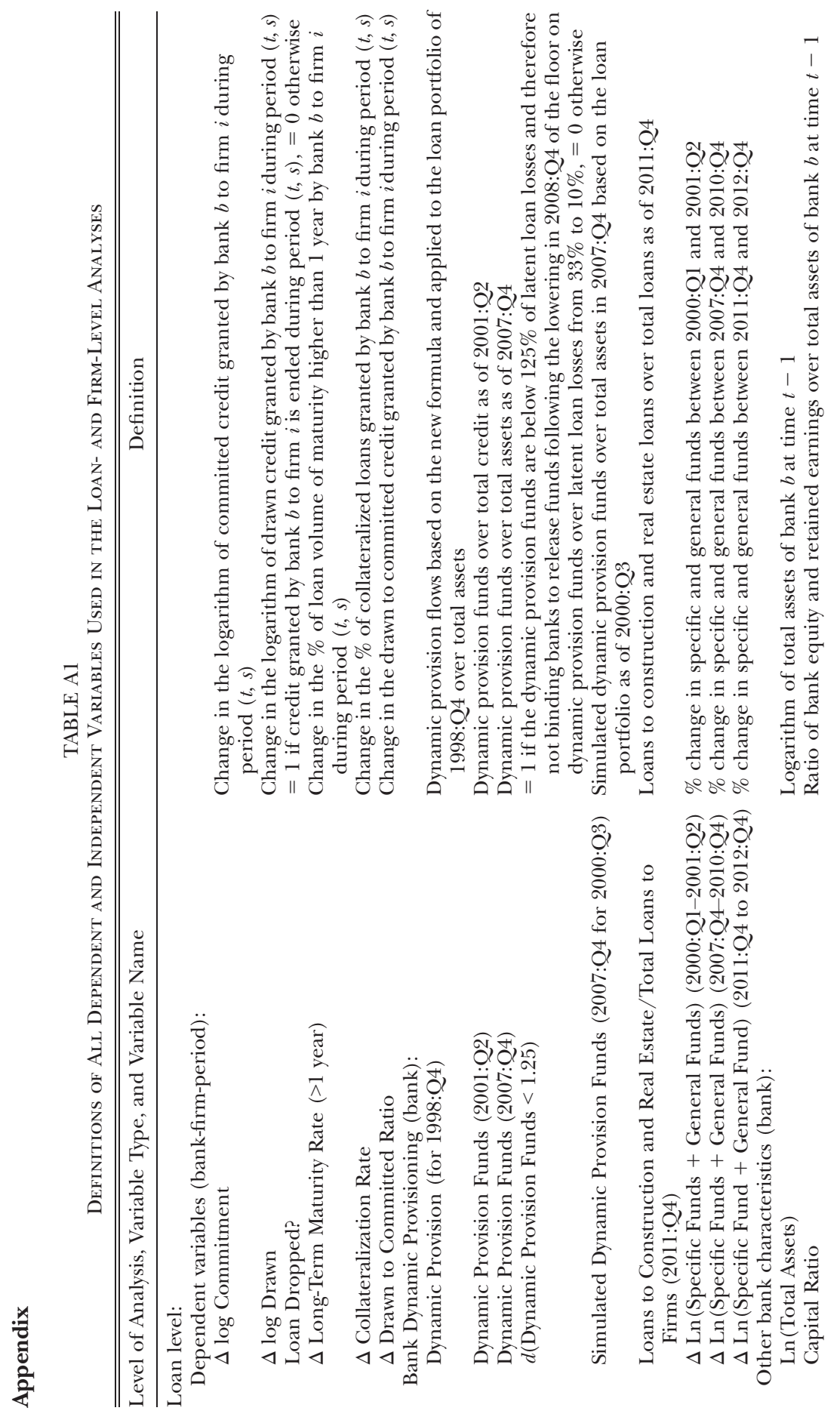

This content downloaded from 084.089.157.043 on April 09, 2019 09:14:29 AM All use subject to University of Chicago Press Terms and Conditions (http://www.journals.uchicago.edu/t-and-c). 


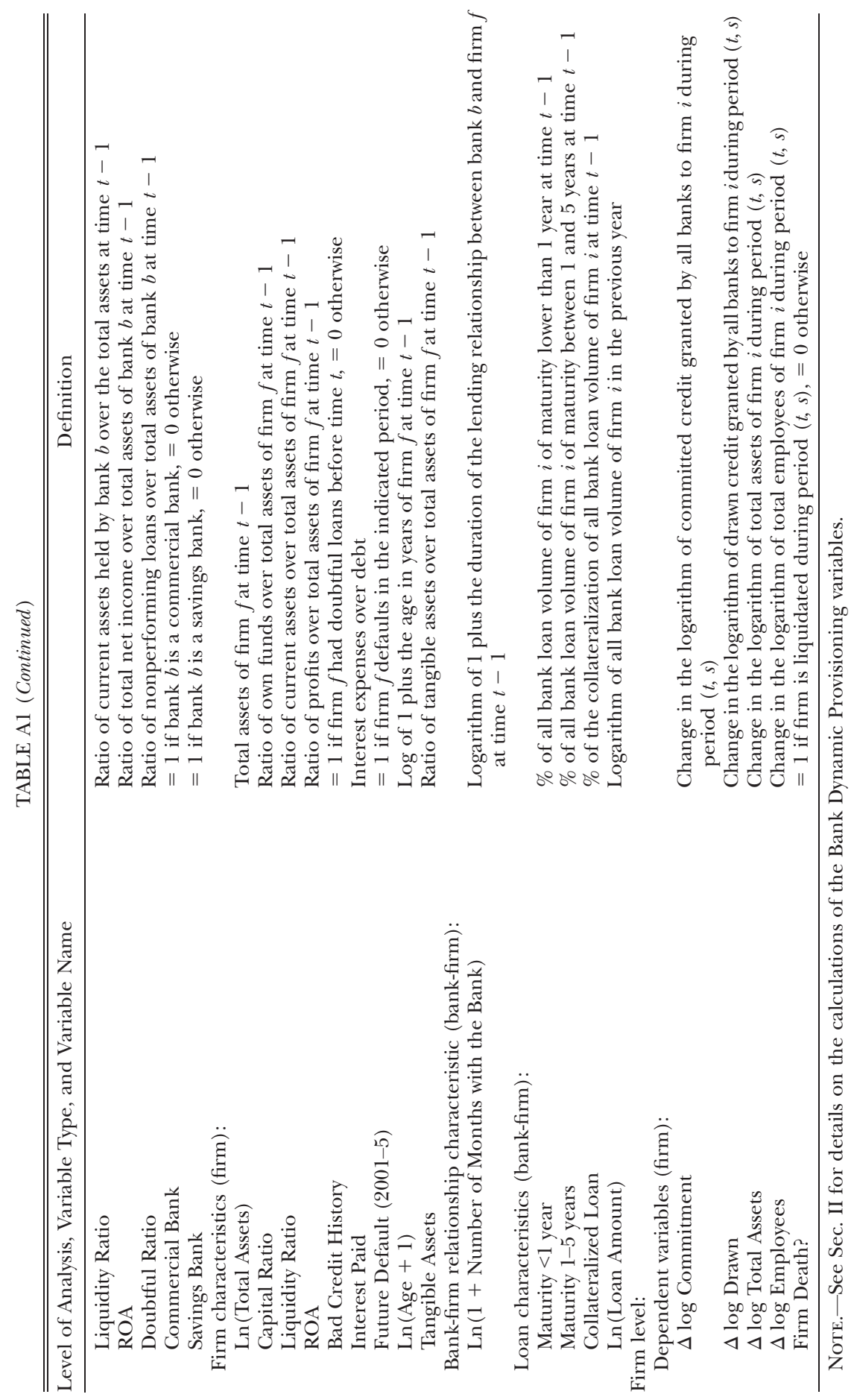

This content downloaded from 084.089.157.043 on April 09, 2019 09:14:29 AM All use subject to University of Chicago Press Terms and Conditions (http://www.journals.uchicago.edu/t-and-c). 


\section{References}

Admati, A. R., and M. F. Hellwig. 2013. The Bankers'New Clothes: What's Wrong with Banking and What to Do about It. Princeton, NJ: Princeton Univ. Press.

Adrian, T., and H. S. Shin. 2011. "Financial Intermediaries and Monetary Economics." In Handbook of Monetary Economics, vol. 3A, edited by B. M. Friedman and M. Woodford, 601-50. New York: Elsevier.

Aiyar, S., C. W. Calomiris, and T. Wieladek. 2014. "Does Macro-Pru Leak? Evidence from a UK Policy Experiment." L. Monev, Credit, and Banking 46:181-214.

Allen, F., and D. Gale. 2007. Understanding Financial Crises. New York: Oxford Univ. Press.

Banco de España. 2004. "Entidades de crédito: Normas de información financiera pública y reservada y modelos de estados financieros." Circular, Banco de España, Madrid.

Berger, A. N., and G. F. Udell. 1994. "Did Risk-Based Capital Allocate Bank Credit and Cause a 'Credit Crunch' in the United States?” L. Monev. Credit, and Banking 26:585-628.

- 2004. "The Institutional Memory Hypothesis and the Procyclicality of Bank Lending Behavior." L. Financial Intermediation 13:458-95.

Bernanke, B. S. 1983. "Nonmonetary Effects of the Financial Crisis in the Propagation of the Great Depression.” A.E.R. 73:257-76.

Bernanke, B. S., and M. Gertler. 1989. "Agency Costs, Net Worth, and Business Fluctuations." A.E.R. 79:14-31.

Bernanke, B. S., and C. S. Lown. 1991. "The Credit Crunch.” Brookings Papers Econ. Activity (2): 205-39.

Borio, C. 2003. "Towards a Macroprudential Framework for Financial Supervision and Regulation." CESifo Econ. Studies 49:181-215.

Chodorow-Reich, G. 2014. "The Employment Effects of Credit Market Disruptions: Firm-Level Evidence from the 2008-09 Financial Crisis." O.J.E. 129:1-59.

Dell'Ariccia, G., and R. Marquez. 2006. "Lending Booms and Lending Standards." I. Finance 61:2511-46.

Dewatripont, M., and J. Tirole. 2012. "Macroeconomic Shocks and Banking Regulation." I. Monev. Credit, and Banking 44:237-54.

Diamond, D. W., and R. G. Rajan. 2001. "Liquidity Risk, Liquidity Creation, and Financial Fragility: A Theory of Banking." L.P.E. 109:287-327.

. 2006. "Money in a Theory of Banking." A.E.R. 96:30-53.

Farhi, E., and I. Werning. 2014. "A Theory of Macroprudential Policies in the Presence of Nominal Rigidities." Manuscript, Harvard Univ.

Fernández de Lis, S., J. Martínez Pagés, and J. Saurina. 2000. "Credit Growth, Problem Loans and Credit Risk Provisioning in Spain." Working paper, Banco de España, Madrid.

Flannery, M. J., and K. P. Rangan. 2008. "What Caused the Bank Capital Build-Up of the 1990s?" Rev. Finance 12:391-429.

Freixas, X., L. Laeven, and J.-L. Peydró. 2015. Systemic Risk, Crises and Macroprudential Policy. Cambridge, MA: MIT Press.

Freixas, X., and J. C. Rochet. 2008. Microeconomics of Banking. Cambridge, MA: MIT Press.

Gale, D. 2010. "Capital Regulation and Risk Sharing." Internat J. Central Banking 6:187-204.

Gale, D., and O. Özgür. 2005. "Are Bank Capital Ratios Too High or Too Low? Incomplete Markets and Optimal Capital Structure." L. European Econ. Assoc. 3: 690-700. 
Gersbach, H., and J.-C. Rochet. 2012. "Aggregate Investment Externalities and Macroprudential Regulation." I. Monev. Credit, and Banking 44:73-109.

Gourinchas, P.-O., and M. Obstfeld. 2012. "Stories of the Twentieth Century for the Twenty-First." American Econ. L.: Macroeconomics 4:226-65.

Guttentag, J., and R. Herring. 1984. "Credit Rationing and Financial Disorder." L. Finance 39:1359-82.

Hanson, S., A. K. Kashyap, and J. C. Stein. 2011. "A Macroprudential Approach to Financial Regulation." L. Econ. Perspectives 25:3-28.

Harris, M., C. C. Opp, and M. M. Opp. 2015. "The System-Wide Effects of Bank Capital Regulation on Credit Supply and Risk-Taking.” Manuscript, Univ. Chicago.

Holmstrom, B., and J. Tirole. 1997. "Financial Intermediation, Loanable Funds, and the Real Sector." O.J.E. 112:663-91.

Jeanne, O., and A. Korinek. 2012. "Managing Credit Booms and Busts: A Pigouvian Taxation Approach." Working paper, NBER, Cambridge, MA.

Jiménez, G., A. Mian, J.-L. Peydró, and J. Saurina. 2014. “The Real Effects of the Bank Lending Channel.” Manuscript, Banco de España, Madrid.

Jiménez, G., S. Ongena, J.-L. Peydró, and J. Saurina. 2012. "Credit Supply and Monetary Policy: Identifying the Bank Balance-Sheet Channel with Loan Applications." A.E.R. 102:2301-26.

_ 2014. "Hazardous Times for Monetary Policy: What Do Twenty-Three Million Bank Loans Say about the Effects of Monetary Policy on Credit RiskTaking?" Econometrica 82:463-505.

Kashyap, A. K., R. Berner, and C. A. E. Goodhart. 2011. "The Macroprudential Toolkit." IMF Econ. Rev. 59:145-61.

Khwaja, A. I., and A. Mian. 2008. "Tracing the Impact of Bank Liquidity Shocks: Evidence from an Emerging Market." A.E.R. 98:1413-42.

Kim, D., and A. M. Santomero. 1988. "Risk in Banking and Capital Regulation." L. Finance 43:1219-33.

Kindleberger, C. P. 1978. Manias, Panics, and Crashes: A History of Financial Crises. New York: Basic Books.

Kiyotaki, N., and J. Moore. 1997. "Credit Cycles.” L.P.E. 105:211-48.

Koehn, M., and A. M. Santomero. 1980. "Regulation of Bank Capital and Portfolio Risk." L. Finance 35:1235-44.

Korinek, A., and A. Simsek. 2016. "Liquidity Trap and Excessive Leverage." A.E.R. 106:699-738.

Laeven, L., and G. Majnoni. 2003. "Loan Loss Provisioning and Economic Slowdowns: Too Much, Too Late?" I. Financial Intermediation 12:178-97.

Lim, C. H., F. Columba, A. Costa, et al. 2011. "Macroprudential Policy: What Instruments and How to Use Them? Lessons from Country Experiences." Working paper, Internat. Monetary Fund, Washington, DC.

Lorenzoni, G. 2008. "Inefficient Credit Booms." Rev. Econ. Studies 75:809-33.

Malherbe, F. 2015. "Optimal Capital Requirements over the Business and Financial Cycles." Working paper, European Central Bank, Frankfurt.

Matsuyama, K. 2007. "Credit Traps and Credit Cycles." A.E.R. 97:503-16.

Morrison, A., and L. White. 2005. "Crises and Capital Requirements in Banking." A.E.R. 95:1548-72.

Peek, J., and E. S. Rosengren. 2000. "Collateral Damage: Effects of the Japanese Bank Crisis on Real Activity in the United States." A.E.R. 90:30-45.

Rajan, R. G. 1994. "Why Bank Credit Policies Fluctuate: A Theory and Some Evidence." O. I.E. 109:399-441.

Reinhart, C. M., and K. S. Rogoff. 2009. "The Aftermath of Financial Crises.” A.E.R. 99:466-72. 
Repullo, R., J. Saurina, and C. Trucharte. 2010. "Mitigating the Pro-cyclicality of Basel II.” Econ. Policy 64:659-702.

Ruckes, M. 2004. "Bank Competition and Credit Standards." Rev. Financial Studies 17:1073-1102.

Saurina, J. 2009a. Dynamic Provisioning: The Experience of Spain. Crisis Response: Public Policy for the Private Sector. Washington, DC: World Bank.

2009b. "Loan Loss Provisions in Spain: A Working Macroprudential Tool." Revista de Estabilidad Financiera Banco de España 17:11-26.

Schularick, M., and A. M. Taylor. 2012. "Credit Booms Gone Bust: Monetary Policy, Leverage Cycles, and Financial Crises, 1870-2008." A.E.R. 102:1029-61.

Shleifer, A., and R. W. Vishny. 2010. "Unstable Banking." L. FinancialEcon. 97:30618.

Tirole, J. 2011. “Systemic Risk Regulation.” 20th Lecture, Barcelona Grad. School Econ., March 31.

Yellen, J. L. 2011. "Pursuing Financial Stability at the Federal Reserve.” Speech at the Fourteenth Annual International Banking Conference, Fed. Reserve Bank Chicago, November 11. 